\title{
National Human Rights Institutions (NHRIs) in
}

\section{ASEAN \\ A Comparative Analysis of the Protection Capacity and Impacts on Performances of NHRIs in the Philippines and Thailand}

\author{
Stanati Netipatalachoochote \\ PhD researcher, Faculty of Law; the Groningen Research Center for South- \\ east Asia and ASEAN, Faculty of Spatial Sciences, University of Groningen, \\ Groningen, the Netherlands \\ s.netipatalachoochote@rug.nl \\ Aurelia Colombi Ciacchi \\ Professor of Law and Governance, Faculty of Law, University of Groningen, \\ Groningen, the Netherlands; Member of the Board of the Netherlands \\ Institute for Law and Governance \\ a.l.b.colombi.ciacchi@rug.nl \\ Ronald Holzhacker \\ Professor of Multilevel Governance and Regional Structure, Faculty of \\ Spatial Sciences, University of Groningen, Groningen, the Netherlands; \\ Director of the Groningen Research Center for Southeast Asia and ASEAN \\ r.l.holzhacker@rug.nl
}

\begin{abstract}
This paper analyses and compares the protection capacity of National Human Rights Institutions (NHRIs) in the Philippines and Thailand, as well as the impact of governmental action on their performances. Here, protection capacity means the extent to which the law authorizes the NHRIs to carry out protective functions in dealing with human rights violations. This comparison evidences that the Philippines' NHRI has greater protection capacity and much more stable mandates than the Thai NHRI. Moreover, although the two NHRIs share the same core mandates to receive complaints of human rights violations, to investigate them, recommendation of remedial measures to the concerned parties, and referral to legal channels, the ways in which
\end{abstract}


these mandates are carried out in the two countries differ. Also the legal and political means by which the governments of both countries have impacted the NHRIs' performances, differ considerably.

\section{Keywords}

ASEAN - South-East Asia - human rights - National Human Rights Institutions (NHRIs) - the Commission on Human Rights of the Republic of the Philippines (CHRP) - the National Human Rights Commission of Thailand (NHRCT)

\section{1 \\ Introduction}

In the past few decades, there has been a rapid worldwide upsurge of the establishment of National Human Rights Institutions (NHRIs), mandated to deal with human rights issues at the domestic level. ${ }^{1}$ The first International Workshop on National Institutions for the Promotion and Protection of Human Rights took place in Paris on 7-9 October 1991. It was organized by the French Commission nationale consultative des droits de l'homme (known as the first NHRI ever created $)^{2}$ in conjunction with the United Nations Centre for Human Rights, which is now called the Office of the United Nations High Commissioner for Human Rights (OHCHR). ${ }^{3}$ This event resulted in the adoption of the 'Paris Principles', endorsed by the Commission on Human Rights in 1992, and the United Nations General Assembly in $1993 .{ }^{4}$ The Paris Principles regulate the functions, operation, and composition of NHRIs. ${ }^{5}$ The NHRIs' status,

1 UNDP-OHCHR. 2010. 'Toolkit for Collaboration with National Human Rights Institutions'. Retrieved 29 November 2019, https://www.ohchr.org/Documents/Countries/NHRI/1950-UNDPUHCHR-Toolkit-LR.pdf, p.3; Anne Smith, 'The Unique Position of National Human Rights Institutions: A Mixed Blessing?', Human Rights Quarterly 28(4) (2006) 904-946; Ryan Welch, 'National Human Rights Institutions: Domestic implementation of international human rights law', Journal of Human Rights 16(1) (2017) 96-116 at 99; Jeong-Woo Koo and Francisco Ramirez, 'National incorporation of global human rights: Worldwide expansion of national human rights institutions 1966-2004', Social Forces 87(3) (2009) 1321-1354.

2 Gauthier de Beco and Rachel Murray, A Commentary on the Paris Principles on National Human Rights Institutions (Cambridge University Press, 2014) 3.

3 Anna-Elina Pohjolainen, 'The Evolution of National Human Rights Institution: The Role of United Nations', The Danish Institute for Human Rights (2006) 1-3.

4 Ibid, 4-5.

5 Andrew Brynes, Andrea Durbach, and Catherine Renshaw, 'Joining the club: the Asia Pacific Forum of National Human Rights Institutions, the Paris Principles, and the advancement of human rights protection in the region', Australian Journal of Human Rights 14 (1) (2008) 63-98. 
pursuant to the Paris Principles, is officially classified by the Sub-Committee on Accreditation of the Global Alliance of National Human Rights Institutions (GANHRI) (formerly known as the International Coordinating Committee of National Human Rights Institutions (ICC). ${ }^{6} 122$ NHRIs worldwide have been accredited by the GANHRI, their statuses being acclaimed as either 'A: Fully compliant'; 'B: Partially compliant'; or 'C: Non-compliant'. ${ }^{7}$

This paper focuses on NHRIs in the Association of Southeast Asian Nations (ASEAN). NHRIs have been established in five of the ten ASEAN member states: the Philippines, Indonesia, Malaysia, Thailand, and Myanmar. These five N HRIs play an indispensable role in promoting and protecting human rights. A few scholars have studied and written on NHRIs in Southeast Asia with a comparative approach. For example, Crouch analyzed the legal transplants and rule of law reform on N HRIs of Myanmar and Indonesia. ${ }^{8}$ Also De Lang examined and compared the development of the N HRIs of these two countries, and made suggestions on how Myanmar should learn from Indonesia. ${ }^{9}$ Setiawan's book compared the promotion of human rights by the NHRIs of Indonesia and Malaysia. ${ }^{10}$ Stokke assessed the implementation of the Paris Principles in three countries' NHRIs namely Indonesia, Malaysia, and the Philippines. He found that these three N H RIs fulfil the requirements of the Paris Principles, but there is still room to improve in terms of legal mandates, composition, and independence. ${ }^{11}$

The present paper compares the NHRIs of two countries with a record of worsening human rights violations over the past few years: the Philippines and Thailand. These NHRIs are the Commission on Human Rights of the Republic of the Philippines (hereinafter CHRP), and the National Human Rights Commission of Thailand (hereinafter NHRCT). This study is innovative both because no comparative research has been done specifically on these two

6 See https://www.ohchr.org/en/countries/nhri/pages/nhrim ain.aspx.

7 The Global Alliance of National Human Rights Institutions (GAN HRI). 2019. 'Chart of the Status of National Institutions.' 4 March. Retrieved 29 November 2019, https://nhri.ohchr .org/EN/Documents/Status\%20Accreditation\%20Chart\%20\%2804\%20March\%202019 .pdf.

8 Melissa Crouch, 'Asian Legal Transplants and Rule of Law Reform: National Human Rights Commission in Myanmar and Indonesia', Hague Journal on the Rule of Law 5 (2013) 146-177.

$9 \quad$ Niki Esse de Lang, 'The Establishment and Development of the Myanmar National Human Rights Commission and Its Conformity with International Standard', Asia-Pacific Journal on Human Rights and The Law 13(1) (2012) 1-41.

10 Ken Marijtje Prahari Setiawan, Promoting human rights: National Human Rights Commissions in Indonesia and Malaysia (Leiden: Leiden University Press, 2013).

11 Hugo Stokke, 2007. 'Taking the Paris Principles to ASIA, A Study of Three Human Rights Commissions in Southeast Asia: Indonesia, Malaysia and the Philippines', сMI Report. Retrieved 29 November 2019, www.cmi.no/publications/2680-taking-the-paris-principles -to-asia. 
NHRIs, and because of the lack of any previous comparative studies involving the Thai NHRI.

The Philippines and Thailand are an interesting subject of analysis for four reasons. Firstly, both of them are being kept an eye on by regional and global peers because of the massive human rights violations still occurring in the two countries, despite the presence of NHRIs. In the Philippines, the most severe human rights violations stem from President Rodrigo Duterte's 'War on Drugs' whereby the police and vigilantes are allegedly engaged in the extrajudicial killings of approximately 20,000 people suspected of being involved in the illegal drug trade. ${ }^{12}$ The President himself vowed that this war will continue and be as chilling and bloody as the day it started..$^{13}$ In Thailand, since the coup d'état in 2014, the military government's orders and policies have particularly targeted political dissenters, especially infringing upon their rights of assembly and freedom of expression. ${ }^{14}$ Even though Thailand held a general election in March 2019, the new government is still empowered by the previous military regime (same prime minister, same cabinet team) and human rights are still disregarded.

Secondly, the difference between the motivations for the establishment of these two NHRIs is rather intriguing. On the one hand, the main reason behind the establishment of the CHRP was to safeguard the people against human rights violations which the Philippines had suffered from during a certain political era. In 1986, President Corazon Aquino who succeeded that era confirmed her public commitment by creating a Presidential Committee on $\mathrm{Hu}-$ man Rights to investigate abuses committed by her predecessor, Ferdinand Marcos', regime. After that, the Committee was replaced by the CHRP which is established under Article XIII of the 1987 Constitution, and whose existence

12 David T. Johnson and Jon Fernquest, 'Governing through Killing: The War on Drugs in the Philippines', Asian Journal of Law and Society (2018) 1-32; Alexis Romero, 2017. 'Duterte Gov't Probing Over 16,00o Drug War-Linked Deaths as Homicide, not EJ K,', Philippine Star. 26 December. Retrieved 29 November 2019, www.philstar.com/headlines/2017/12/26/ 1771944/duterte-govt-probing-over-16ooo-drug-war-linked-deaths-homicide-not-ejk; Felipe Villamor, 2018. 'Philippines Plans to Withdraw from International Criminal Court', New York Times. 14 March. Retrieved 29 November 2019, www.nytimes.com/2018/03/14/world/ asia/rodrigo-duterte-philippines-icc.html.

13 Karen Lema and Neil Jerome Morales, 2018. 'Philippines' Duterte to keep up 'relentless and chilling' drugs war', Reuter. 23 July. Retrieved 29 November 2019, www.reuters.com/ article/us-philippines-duterte/philippines-duterte-to-keep-up-relentless-and-chilling -drugs-war-idUSKBN1KD133.

14 Human Rights Watch. 2018. 'World Report: Thailand Event of 2017'. Retrieved 29 November 2019, www.hrw.org/world-report/2018/country-chapters/thailand; Amnesty International. 2018. 'Amnesty International Report: Thailand 2017/2018'. Retrieved 29 November 2019,www.amnesty.org/en/countries/asia-and-the-pacific/thailand/report-thailand/. 
was also officially declared by Executive Order No. 163. On the other hand, in Thailand, the NHRCT's establishment mainly derived from the desire to reform state organs during Prime Minister Banharn Silpa-archa's tenure in $1995 \cdot{ }^{15}$ During the drafting process of the Thai Constitution 1997, the government tried to set up state organs to be more up to par with international standards, especially by creating new significant national institutions. The NHRCT, established under this Constitution, was one of such reforms.

The third reason why it is worthwhile to compare the NHRIs of the Philippines and Thailand pertains to the establishing laws which provided mandates for the two NHRIs. The five NHRIs in ASEAN have different establishing laws. The Indonesian and Myanmar N H Ris were established by Presidential Decrees whereas the Malaysian NHRI was born out of a Parliamentary Act. In contrast, the Thai and Philippine NHRIs were established by Constitutions. The NHRCT was established a decade later than the CHRP. While the CHRP's mandates, provided in the 1987 Constitution, have never been changed, the NHRCT's mandates have been amended overtime based on the change of the Constitutions in 1997, 2007, and 2017, because of the domestic political conflicts which occurred every decade in Thailand.

The fourth and last reason why the CHRP and NHRCT have been chosen as subjects of comparison consists in the status granted by the Sub-Committee on Accreditation (SCA) of the GANHRI. From the accreditation session which took place on 8 August 2018 it resulted that the Philippines' NHRI holds an 'A' status, while the status of the Thai NHRI has been downgraded from 'A' to 'B'. Since human rights violations still exist in both countries, and both governments seem to be rather more pro-security than pro-human rights, it is interesting to see in which regards the protection capacities of the two N HRIs differ. This requires both a comparative study of their protective mandates, to ascertain to what extent the laws of both countries authorize their NHRIs to protect human rights, and an assessment of how the two NHRIs' mandates work in the actual political context.

Research Questions, Methodology, and Structure

This paper aims at answering two research questions:

1. To what extent does the law provide protective capacity to the CHRP and NHRCT in dealing with human rights cases?

15 Montri Roobsuwan, The Spirit of The Constitution: The Thai Constitution B.E. 2540 (Bangkok: Winyuchon Publisher, 1999) 23, 310. 
2. How have the governments of the Philippines and Thailand impacted the performances of the CHRP and NHRCT in carrying out human rights protection work?

The methodology of this research combines the analysis of legal and policy documents with empirical insights. Firstly, we support our arguments by analyzing official documents and reports in connection with human rights institutions in the Philippines and Thailand. For instance, the 2015-2018 annual reports of the CHRP and NHRCT, and annual reports from civil society organizations such as the ANNI Report on Performance and Establishment of National Human Rights Institutions in Asia will provide a significant source of information. Secondly, in addition to the analysis of legal and policy documents, another principal source of this research are personal interviews and discussions with the Chairperson and staff of NHRIs of the Philippines and Thailand. Opinions and field experiences of such interviewees make them pertinent and insightful information providers.

In terms of data, this paper examines the protection capacity of NHRIs and the factors which contribute to impacting the performance of their work using recent facts. We analyze information concerning the present administration of the Philippines under President Rodrigo Duterte since 2016 which saw the incident of extrajudicial killings and many related human rights violations, and information concerning Thailand under the military government since 2014, which saw a rise in human rights violations by the government. On the background of this information, this paper provides an up-to-date analysis on how the CHRP and NHRCT's protection capacities are implemented in the current human rights circumstances.

The present comparative study between the CHRP and NHRCT is divided into two parts, mirroring the above-mentioned two research questions. The first part begins with a broad comparative overview of the legal bases of all NHRIS of ASEAN member states. It then compares the protection capacity of the CHRP and NHRCT by analyzing the differences in the legal bases of the NHRIs' protective mandates, the differences in the stability of these mandates, and the differences in the protective powers included in these mandates. As a benchmark for comparison, this paper uses the following list of protective powers: (1) to receive complaints, (2) to make complaints to an inquiry officer, (3) to investigate, (4) to protect witnesses, (5) to prosecute, (6) to make recommendations and suggest remedial measures, (7) to visit detention facilities, and (8) to provide financial aid. The reason why we focus on these eight powers consists in the fact that they are included, or were included in the past and then subsequently withdrawn, in the legislative provisions about the NHRIs mandates in either the Philippines or Thailand or both. 
The second part focuses on the impacts to the performances of both N HRIs. In this part, we point out and compare a variety of ways by which the governments of the Philippines and Thailand have impacted the actual exercise of their NHRI's protective mandates. We note that even though both the CHRP and NHRCT were established by the highest law of the state, namely the Constitution, both NHRIs are still hindered by their governments whose policy and political wills are not pro-human rights. In the Philippines, the main impact to human rights protection work in the case of extrajudicial killings stems from President Duterte's war on drugs policy. In Thailand, the frequent changes of the Constitution overtime which made the functions of the NHRCT unstable, only represent a first impact. Other prominent impacts have been set by the military government that rules the state since 2015. The findings of our research lead us to formulate, in the concluding section of this paper, some recommendation for improvement of the human rights situation in the Philippines and Thailand.

NHRIS in ASEAN: A Comparative Overview

As of 2019, only five of the ten member states of the Association of Southeast Asian Nations (ASEAN) have established NHRIs. The first one is the Commission on Human Rights of the Philippines (CHRP) which goes back to 1987, thus even before the emergence of the Paris Principles. It was established under the Constitution by President Cory Aquino after the massive human rights abuses under President Marcos' regime. ${ }^{16}$ The second NHRI in this region was established in Indonesia in June 1993 by President Decree No. 50/1993. ${ }^{17}$ It is called the National Commission on Human Rights, also known as KomnAs HAM. The international pressure in reaction to the massacre of the people of East Timor put President Suharto on agenda to play a significant role in the formation of the Indonesian NHRI. ${ }^{18}$

In 1997, Thailand had emphasized on the idea of having a NHRI which finally the National Human Rights Commission of Thailand (NнRCT) established in accordance with the Constitution of the Kingdom of Thailand of 1997, with the main purpose to reform the state's legal, administrative and political

16 Emma Palmer, 'The effectiveness of National Human Rights Institutions' relationships with civil society: the Commission on Human Rights in the Philippines', Australian Journal of Human Rights (2019) 5-6.

17 See https://www.komnasham.go.id/index.php/about/1/tentang-komnas-ham.html.

18 Ken Marijtje Prahari Setiawan, Promoting human rights (n 10). 
systems. ${ }^{19}$ During the same period, Malaysia also established its NHRISurahanjaya Hak Asasi Manusia Malaysia, or SU HAKAм in brief. ${ }^{20}$ The Malaysian parliament passed the Bill establishing the NHRI in September 1999 as the Human Rights Commission of Malaysia Act (597/1999). This Act provided suHAKAM mandates and functions that have remained unchanged until the present. ${ }^{21}$ The reasons behind the creation of the SUHAKAM are quite similar to the ones that lead to the establishment of the KOMNAS HAM of Indonesia namely improving the state's international reputation and avoiding external critiques on human rights abuses and violations. One might even argue that paradoxically, in Malaysia and Indonesia, the NHRIs were mainly established to legitimize human rights violations. ${ }^{22}$ However, it is interestingly noted that NGOS are also an actor behind the process of creation of the NHRIs in these two countries. ${ }^{23}$

The most recent NHRI in ASEAN is the Myanmar National Human Rights Commission (MNHRC). Myanmar also took heavy criticism from a number of countries for its massive human rights abuses during the Universal Periodic Review (UPR). ${ }^{24}$ This created the need to introduce a NHRI. ${ }^{25}$ Finally the MNHrC was established by Presidential Notification No. 34/2011 dated 5 September 2011. This document states that the MNHRC was formed with 'a view to promoting and safeguarding fundamental rights of citizens described in the Constitution of the Republic of the Union of Myanmar.26

Eventually, the ASEAN NHRIs have been reviewed under the accreditation system of the Global Alliance of National Human Rights Institutions (GANH RI), formerly known as the International Coordinating Committee of National Human Rights Institutions (ICC). According to the accreditation session of 2018, three Southeast Asian NHRIs - Indonesia, Malaysia, the Philippines — hold

19 Montri Roobsuwarn, The Spirit of the Constitution (n 15) 309-313.

20 See https://www.suhakam.org.my/about-suhakam/.

21 Ibid.

22 Ken Marijtje Prahari Setiawan, Promoting human rights (n 10).

23 Ibid.

24 A few Southeast Asian countries raised this point. See UN Human Rights Council, 17th session, 'Report of the Working Group on the Universal Periodic Review, Myanmar' A/HRC/17/9 (24 March 2011) paras 106(23)-106(30) 'Thailand: Establish a National Human Rights Commission in line with the Paris Principles to provide for effective promotion and protection of human rights at the national level; Indonesia: Upgrade its human rights body into an independent and credible National Human Rights Institution in accordance with the Paris Principles'.

25 Niki Esse de Lang, 'The Establishment and Development of the Myanmar National $\mathrm{Hu}-$ man Rights Commission and Its Conformity with International Standard' (n 9) 11-13.

26 See http://www.mnhrc.org.mm/en/about/about-the-commissioner/. 
the 'A' status, while the Myanmar National Human Rights Commission (MNHRC) is granted a 'B' status, and the status of the National Human Rights Commission of Thailand (NHRCT) has been downgraded from 'A' to 'B'.

The table below briefly illustrates, in a chronological order, the legal bases for the creation of the ASEAN NHRIS.

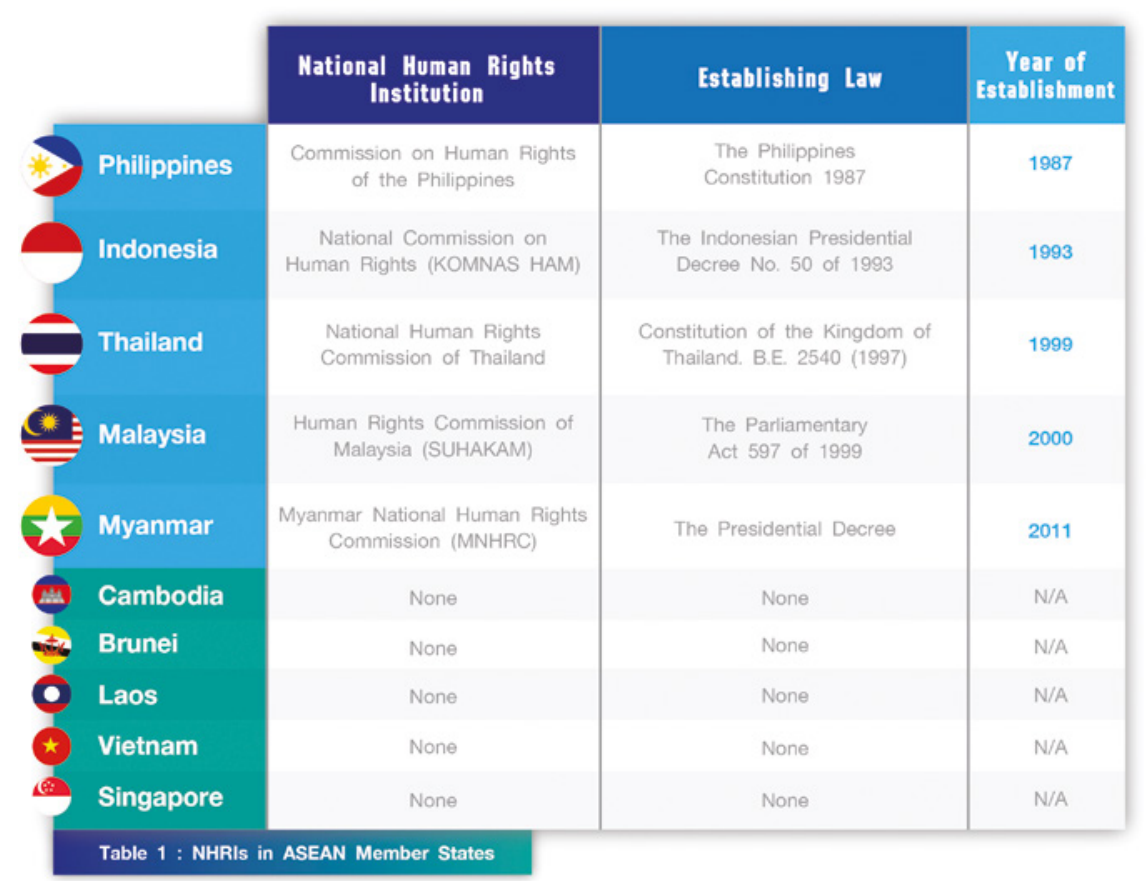

As shown in table 1 , no NHRIs exist in the five remaining ASEAN member states, namely, Cambodia, Brunei, Lao PDR, Vietnam and Singapore. These states have their own human rights bodies which are not accredited as types of NHRIs by the GANHRI. These bodies are subject to governmental control, depriving them of the independent status required for the existence of a NHRIs.

In Cambodia, there is a National Assembly Commission on Human Rights (NACHR) which works under the National Assembly, a Senate Commission on Human Rights (sCHR) which works under the Senate, and the Cambodian Human Rights Committee which was established in 1998, and assigned by the royal government. ${ }^{27}$ Brunei has been governed by a Sultan for many decades.

27 David Cohen, Kavin Tan and Aviva Nababan, 'Update on the Rule of Law for Human Rights in ASEAn: The Path to Integration', Human Rights Resource Centre (2016) 8-9. 
No provision of the Constitution of 1959 guarantees human rights and fundamental freedoms. ${ }^{28}$

Lao PDR has adopted and amended the Constitution in 1991 and 2003 respectively. ${ }^{29}$ Article 6 of the 2003 Constitution provides: 'The State protects the freedom and democratic rights of the people which cannot be violated by anyone. ${ }^{30}$ In the Laotian Constitution, provisions on the fundamental rights of the citizens are enshrined, which include civil, political, economic, social and cultural rights. ${ }^{31}$ This country has established the National Commission for the Advancement of Women, Mothers and Children; the National Committee for Disabled People; the National Committee for Rural Development and Poverty Alleviation; and the National Committee against Human Trafficking.

In Vietnam, the 1992 Constitution (as amended in 2001) recognizes that '( $i$ ) $\mathrm{n}$ the Socialist Republic of Vietnam, human rights in all respects, political, civic, economic, cultural and social are respected, find their expression in the rights of citizens and are provided for by the Constitution and the law'.32 However, there is neither a NHRI in Vietnam, nor do any specific sub-national human rights bodies, such as those in Cambodia and/or Lao PDR, exist.

Singapore is arguably the most urbanized and developed country in ASEAN. However, with respect to human rights, this country has been criticized as ignorant. ${ }^{33}$ National institutions related to human rights seem to only include the Corrupt Practices Investigation Bureau (CPIB) which investigates and prosecutes corruption cases. ${ }^{34}$ The СРIB is a government agency under the Prime Minister's Office, and independent from all other government agencies, including the Singaporean Police Force. ${ }^{35}$

28 Ibid, 5 .

29 Ibid, 3-4.

3o The Constitution of the Lao People's Democratic Republic, Article 6.

31 Ibid, Article 34-41.

32 The Constitution of the Socialist Republic of Vietnam, Article 50.

33 Human Rights Watch. 2017. 'Singapore: Laws Chill Free Speech, Assembly: End Repressive Prosecutions, Regulations, and Civil Suits'. 13 December. Retrieved 29 November 2019, www.hrw.org/news/2017/12/13/singapore-laws-chill-free-speech-assembly.

34 See https://www.cpib.gov.sg/about-cpib/roles-and-functions.

35 Ibid. 


\section{Protection Capacity of NHRIS}

\subsection{Approaches Proposed in the Literature}

The functions of NHRIs depend on their mandates according to the legal documents which established them. It has been maintained that NHRIs should be formed by a Constitution or a legislative act, rather than by executive order or decree, since a Constitution-based NHR I will be more active or promising. ${ }^{36}$ In principle, NHRIs with a statutory basis have safeguards of their independence guaranteed: their independence is formally recognized by law, they are less easily abolished, and also less vulnerable to governmental influence. ${ }^{37}$

Scholars have widely discussed the protective functions of NHRIs in several contributions. ${ }^{38}$ NHRIs are usually committed to two main functions: firstly, the promotion of human rights, i.e. creating a national culture of human rights with the application of international human rights norms, conducting public education and providing a focal point of human rights to the public to understand rights and their enforcement; and secondly, the protection of human rights, i.e. helping to identify and investigate human rights violations, to bring those responsible for human rights abuses to justice, and to provide a remedy and redress for victims. ${ }^{39}$

Normally, NHRIs both promote and protect human rights. However, as Cardenas observes, '(i)f NHRIs are not independent, representative, and organizationally powerful, they could be more adept at promoting rather than protecting human rights norms. ${ }^{40}$

NHRIs can make international human rights law more effective domestically as they ensure domestic legal systems fulfill international commitments. Interestingly, research in the context of the international human rights obligation of protection against torture has shown that under certain conditions, 'the presence of an NHRI substantively decreases the chances the state will be an egregious offender.'41

36 Commonwealth Secretariat, 'National Human Rights Institutions: Best Practice', (2001) $10-11$.

37 Anne Smith, 'the Unique Position of National Human Rights Institutions' (n 1) 914.

38 See also in Stephanie Lagoutte, Annali Kristiansen and Lisbeth Thonbo, 'Review of Literature on National Human Rights Institutions', Danish Institute for Human Rights (2016).

39 Richard Carver, 'Assessing the Effectiveness of National Human Rights Institutions', Versoix: International Council on Human Rights Policy (2005) 17-19.

40 Sonia Cardenas, 'Emerging Global Actors: The United Nations and National Human Rights Institutions', 9 Global Governance 23 (2003) 28.

41 Ryan Welch, 'National Human Rights Institutions' (n 1$) 100$. 
Also, NHRIs can effectively carry out their protection function by focusing on national human rights norms: the provisions of the laws, Constitutions, and/or bill of rights in the domestic legal framework. ${ }^{42}$ NHRIs can help audit legislations to ensure the protection of citizens' rights, and provide to victims a fair legal redress. ${ }^{43}$

In carrying out protection mandates, NHRIs should be independent from the government. They should not only inform citizens of their rights under international human rights law, but also act when an individual's rights are violated by a public body, and lodge a complaint against the state. ${ }^{44}$ NHRIs are defenders of human rights whose mandate the state and its apparatus should undoubtedly need to protect and comply with, even in the event the state or its apparatus are violators themselves ${ }^{45} \mathrm{~N}$ HRIs can carry out states' human rights policies independently of the contentment of social expectations and ensure that, firstly, there is recognition of human rights violations, and secondly, that fair trial and remedies are provided to victims. ${ }^{46}$

NHRIs are an important linkage institution who empowers individuals to know that they do not have to endure human rights violations, so that when violations are committed by the state and its agencies, victims will not have to suffer in silence. Milimo Mayo's research on Zambia shows that NHRIs are key actors in providing victims a place, other than the state apparatus that perpetrated their torture ${ }^{47}$ Once a complaint is in their hands, NHRIs may investigate and decide which action to take to settle the grievance, and sometimes decide to send the case to the court, informing the victims of their rights and provide aid through the legal process. ${ }^{48}$ In addition, sometimes NHRIs can make recommendations to the government to award monetary compensation to victims, such as the Uganda Human Rights Commission which

42 Raj Kumar Chockalingam, 'National Human Rights Institutions: Good Governance Perspectives on Institutionalization of Human Rights', American University International Law Review 19(2) (2003) 259-300 at 279 .

43 Richard Carver, 'A new answer to an old question: National human rights institutions and the domestication of international law', Human Rights Law Review 10(1) (2010) 1-32; Richard Carver, 'National human rights institutions in Central and Eastern Europe', in: Ryan Goodman and Thomas Pegram (eds) Human Rights, State Compliance, and Social Change (New York: Cambridge University Press, 2012) 181-209 at 190.

44 Ryan Welch, 'National Human Rights Institutions' (n 1) 98.

45 Raj Kumar Chockalingam, 'National Human Rights Institutions' (n 42) 285.

46 Ibid.

47 Ryan Welch, 'National Human Rights Institutions' (n 1) 102.

48 Ibid. 
recommended a monetary budget averaging around 20,000,00o Ugandan shilling to victims. ${ }^{49}$

Some NHRIs have quasi-judicial powers, a feature which can also be used as a criterion to assess their protective capacity. ${ }^{50}$ Although judicial institutions are indispensable in the protection of human rights, NHRIs, it is argued, are in a better position to take initial action on human rights violations than the judiciary, which might have limitations under the applicable laws about how and when an issue comes before the court. ${ }^{51}$ NHRIs have less such restraints, but have more relevance to take cognizance on human rights violations. ${ }^{52}$ If N HRIS have powers to directly link with judicial institutions, such institutions can assist NHRIs to guarantee that the protection of human rights is realized. ${ }^{53}$ Greater interaction between judiciaries and NHRIs can significantly aid the enforcement of human rights obligations, especially in the event where NHRIs can pass on complaints of alleged human rights violations within the jurisdiction of national courts. ${ }^{54}$

Moreover, NHRIs' protection capacity can rely on the relationship between NHRIs and regional human rights institutions. NHRIs can make regional human rights concerns robust by spreading rapidly the information on human right situations in the region. ${ }^{55}$ They also help strengthen regional human rights regimes by supporting basic legal principles, and providing information on domestic human rights situations. ${ }^{56}$ Ideally, N H RIs also help realize the judicial protection of human rights at the regional level. For instance, in the African human rights system, NHRIs are entitled to bring cases directly to the African Court on Human and People's Rights. ${ }^{57}$ In Europe, NHRIs can work

49 Uganda Human Rights Commission (U HRC). 2009. 'the 12th Annual Report of the Uganda Human Rights Commission to the Parliament of the Republic of Uganda'. Retrieved 29 November 2019, https://www.rwi.lu.se/NHRIDB/Africa/Uganda/2009\%20Annual\%2oReport.pdf.

5o Anne Smith, 'The Unique Position of National Human Rights Institutions' (n 1) 916.

51 Martin A. Olz, 'Non-Governmental Organizations in Regional Human Rights Systems', Columbia Human Rights Law Review 28 (1997) 343.

52 Ibid.

53 Larry Alexander and Frederick Schauer, 'Defending Judicial Supremacy: A Reply', Constitutional Commentary 17 (2000) 478.

54 Terry Collingsworth, 'The Key Human Rights Challenge: Developing Enforcement Mechanisms', Harvard Human Rights Journal 15 (2002)188-190. See also Vijayashri Sripati, 'India's National Human Rights Commission: A Shackled Commission?' Boston University International Law Journal 18 (2000) 15 .

55 Sonia Cardenas, 'Emerging Global Actors' (n 40) 28.

56 Ibid.

57 Protocol to the African Charter on Human and Peoples' Rights on the Establishment of the African Court on Human and Peoples' Rights, Article. 29, 30; International Federation for Human Rights (FIDH). 2016. 'Admissibility of complaints before the African Court: 
with the European Court of Human Rights through occasionally making amicus curiae interventions, and more generally, by following-up the Court's case law and monitoring and advising on the execution of judgments by national authorities. ${ }^{58}$ In the Inter-American human rights system, NHRIs have been considered as falling within the definition of a person who can lodge petitions with the Inter-American Commission on Human Rights. ${ }^{59}$

Scholars have pointed out different ways of assessing the effectiveness of NHRIS. A convincing taxonomy of the types of approaches proposed in the literature is provided by Mertus. She identifies three groups of approaches to assess NHRIs' effectiveness: (1) structural, (2) mandate-based, and (3) impactbased approaches. ${ }^{60}$ In the structural approaches, the compliance with the Paris Principles is the major criterion to evaluate the effectiveness of NHRIs. ${ }^{61}$ Mandate-based approaches refer to formal-substantive criteria which measure how far a NHRI succeeds in implementing its own mandate. ${ }^{62}$ Impact-based approaches focus on the impact of a NHRI's activities in both promotion and protection terms. ${ }^{63}$

On the one hand, an example of a structural approach can be found in Matshekga's work. He maintains that the effectiveness of NHRIs results from the combination of a plurality of factors: 'legal and operational autonomy, financial autonomy, clear and transparent appointment and dismissal procedures, and the appointment of demonstrably able, independent, and effective commissioners.' ${ }^{64}$

On the other hand, Carver seems to follow a predominantly impact-based approach. He proposes a number of indicators to assess NHRI effectiveness: One would distinguish between output — what has been done, such as

Practical Guide', June. Retrieved 29 November 2019, https://www.fidh.org/IMG/pdf/admissibility_of_complaints_before_the_african_court_june_2016_eng_web-2.pdf.

$5^{8}$ Philip Leach, Taking a Case to the European Court of Human Rights (Oxford University Press, 2017). See also European Convention on Human Rights, Article 34.

59 Linda C. Reif, The Ombudsman, Good Governance and the International Human Rights System (Leiden: Brill, 2004) 178-180. See also the American Convention on Human Rights, Article 44 .

6o Julie Mertus, 'Evaluating NHrIs: Considering Structure, Mandate, and Impact', in: Ryan Goodman and Thomas Pegram (eds) Human Rights, State Compliance, and Social Change: Assessing National Human Rights Institutions, (New York: Cambridge University Press, 2012).

$61 \quad$ Ibid.

62 Ibid.

63 Ibid, 83 .

64 James Matshekga, 'Toothless Bulldogs - The Human Rights Commissions of Uganda and South Africa: A Comparative Study of Their Independence', African Human Rights Law Journal 2(1) (2002) 68-91. 
how many complaints an NHRI has handled, performance - for example, how quickly a complaint has been resolved, and how satisfied victims are, and impact-how effective the work of the NHRI has been in redressing human rights violations. ${ }^{65}$

An impact-based approach is also recognizable in Mubangizi's work, which provides a comparative discussion of the South African and Ugandan Human Rights Commissions. ${ }^{66}$ He remarks that some NHRIs measure their success in numbers: the number of training workshops held, the number of educational/ outreach initiatives undertaken, and how many reports or press releases are published, but these indicators still do not really assess how effective NHRIs are especially in differing political and socio-economic contexts. ${ }^{67}$

Some approaches combine structural, mandate-based, and impact-based elements. For example, Goshu has developed indicators in furtherance of Carver's research which illustrate both the formal legitimacy (relating to the legal framework), and the public legitimacy (relating to practice) to identify the effectiveness of NHRIs. ${ }^{68} \mathrm{He}$ explains that the formal legitimacy which NHRIs should hold are the normative legal basics including independence, composition, and mandate. ${ }^{69}$ The public legitimacy refers to the perception and practice of a NHRI to defend human rights impartially — for instance, through monitoring, investigation, recommendation, and their willingness to take up politically sensitive matter in practice..$^{70}$

Also Murray's work combines structural, mandate-based, and impact-based elements. She argues that the effectiveness criteria go beyond the legal requirements of the Paris Principles, and proposes three approaches-capacity, performance, and legitimacy — to help measure a NHRI's effectiveness. ${ }^{71}$ Capacity refers to a wide variety of factors, including legal status, independence, political support, the existence of democratic state institutions, adequate powers and resources, broad mandate and defined jurisdiction, financial resources,

65 Richard Carver, 'Performance \& legitimacy: national human rights institutions', International Council on Human Rights Policy (2004) 120-123.

66 John C. Mubangizi, 'A Comparative Discussion of the South African and Ugandan Human Rights Commissions', The Comparative and International Law Journal of Southern Africa 48 (1) (2015) 124-143.

67 Ibid, 142.

68 Wondemagegn T. Goshu, 'The Ethiopian [National] Human Rights Commission and Its Contribution to Constitutionalism', Ethiopian Constitutional Law Series 5 (2015) 10, 11.

69 Ibid.

70 Ibid.

71 Rachel Murray, 'National Human Rights Institutions. Criteria and Factors for Assessing their Effectiveness', Netherlands Quarterly of Human Rights 25(2) (2007) 189-220. 
and adequate personnel. ${ }^{72}$ Performance refers to a clear strategic plan and vision, full use of powers and resources, coherent management and operational efficiency, influence, and crisis management. ${ }^{73}$ Finally, legitimacy focuses on the relationships that an NHRI establishes with other key actors such as the government, legislature, the media, NGOS and other civil society bodies. ${ }^{74}$

\subsection{The Protection Capacity Approach Adopted in This Paper}

This paper agrees with Murray's approach in two regards: firstly, for what concerns her position that effectiveness goes beyond the legal requirements of the Paris Principles, and secondly, for what concerns her definition of 'performance.' However, the present paper does not aim at assessing the effectiveness of the CHRP and NHRCT. It only aims at comparing their protection capacity, whereby our definition of 'capacity' differs from Murray's. Because of the legal science focus of this paper, with 'protection capacity' we refer to the whole set of protective powers of a NHRI which have a basis in the respective laws. Some of these protective powers go further than required by the Paris Principles.

As already mentioned in the methodological section above, the protective powers compared in this paper concern the mandates to: (1) receive complaints, (2) make complaints to an inquiry officer, (3) investigate, (4) protect witnesses, (5) prosecute, (6) make recommendations and suggest remedial measures, (7) visit detention facilities, and (8) provide financial aid. The reason why we only consider these eight powers and not others consists in that only these eight have a basis in the Philippines' and/or Thai laws. They are either currently included, or were included in the past and then subsequently withdrawn, in the legislative provisions about the NHRIs mandates in either the Philippines or Thailand or both. Therefore, following Mertus' taxonomy and terminology, one may argue that this paper follows a mandate-based approach.

The comparative analysis contained in the following section will focus on the differences between the two NHRIs' protection capacities. We will also point out how the differences in the constitutions of the Philippines and Thailand affect the mandates of the NHRIs and create different capacities of human rights protection.

$\begin{array}{ll}72 & \text { Ibid. } \\ 73 & \text { Ibid. } \\ 74 & \text { Ibid. }\end{array}$




\subsection{The Philippines: Protective Mandates of the CHR}

Before discussing the details of the CHRP's human rights protection mandates, the factors which underpin the establishment of this NHRI shall be briefly described, because the insight into these factors help us understand the reasons why the CHRP has been mandated certain protection functions. During President Ferdinand Marcos' regime which commenced in 1965, martial law which gave the military more powers was declared. ${ }^{75}$ An increase of powers and financial resources led the military to commit various human rights violations, such as torture, summary executions, and enforced disappearances.

A huge political change occurred after Aquino was proclaimed as President of the Philippines in February $1986 .{ }^{76}$ She straightaway released 500 political prisoners, including top Communist leaders seized in the Marcos detention camps. ${ }^{77}$ Part of the political change included Aquino forming the Presidential Committee on Human Rights (PCHR) to deal with human rights violations, to which Jose Diokno, a respected politician and well-known human rights lawyer and activist, was promoted as head. ${ }^{78}$ Additionally, several human rights lawyers and activists, who had been in lifelong opposition to the dictatorship were appointed to key positions in the new government. ${ }^{79}$ This was a reaction to the rampant violations suffered from the previous regime under President Marcos' rule, ${ }^{80}$ and also raised high hopes for Filipinos who had always dreamed that the notorious human rights violators in the fourteen-year Marcos dictatorship would be brought to justice and meted out due punishment. ${ }^{81}$

The Presidential Committee was further mandated to advise the new government on the appropriate compensation to victims and punishment of culprits as it might deem appropriate, and similarly to 'propose procedures and safeguards to ensure that, under the new government, human rights are not violated by officers or agents of the government, or by persons acting in their

\footnotetext{
75 Michael Allen Fox, Understanding Peace: A Comprehensive Introduction (New York: Routledge, 2014) 58.

76 Belinda Aquino, 'The Human Rights Debacle in the Philippines', in: Naomi Roht-Arriaza (eds.), Impunity and Human Rights in International Law and Practice (New York: Oxford University Press, 1995) 232.

77 Ibid.

78 Ibid.

79 Ibid.

8o Raymund Rosuelo, Chief of the Research, Documentation, and Resources Division of the Commission on Human Rights of the Philippines. (May and June 2019). Telephone interview.

$81 \quad$ Ibid.
} 
name and stead or under their orders, express or implied.82 The PCHR was later abolished by virtue of the Philippines Constitution of 1987 creating the Commission on Human Rights of the Republic of Philippines (CHRP) ${ }^{83}$ This Commission is an independent institution with the purpose to promote and protect human rights, as provided in Article XIII, Section 17-19 of the Philippine Constitution and Section 4 of the Executive Order No. $163 / 1987 .{ }^{84}$ An Executive Order is an act of the President which provides 'rules of a general or permanent character in implementation or execution of constitutional or statutory powers. ${ }^{\prime 5}$

In particular, the mandate of the CHRP can be found in Article XIII, Section 18 of the 1987 Constitution. Section 18(1) - (11) lays out the powers and duties of the CHRP that reflect the Commission's role in the promotion and protection of human rights. Executive Order 163, issued subsequently to the adoption of the Constitution to 'implement the provisions of the Constitution pertaining to the Commission,' mirrors ad verbatim these mandates in its Section $3 \cdot{ }^{86}$

With respect to its protection capacity, in order to fulfill its duty to protect human rights, the CHRP is mandated to carry out various functions. The first prominent function is the power to receive complaints and investigate human rights violations cases. Article XIII, Section 18 (1) provides that the CHRP shall have the powers to investigate, on its own or on complaint by any party, all forms of human rights violations involving civil and political rights. ${ }^{87}$ The CHRP has adopted many Resolutions to clarify this protective function. For example, Res. No. A88 045 (26 July 1988) was issued to define the meaning of human rights violations per se, which is the kind of human rights violation that would be afforded priority by the CHRP. ${ }^{88}$ According to the Resolution, human rights violations per se are those which are, by their very nature, easily and readily discernible as palpable transgressions of the rights defined in the Universal Declaration of Human Rights, the international bill of rights, and other international human rights covenants and treaties to which the Philippines is a State Party. Another resolution, Res. No. A96 005 was issued to clarify that the

$82 \quad$ Ibid.

83 See https://www.officialgazette.gov.ph/constitutions/1987-constitution/.

84 The Constitution of the Republic of the Philippines, Article XIII, Section 17-19. See also Executive Order No. 163 published on Official Gazette, 1987-05-11, Vol. 83, No. 13, 2269-2271.

85 The Administrative Code of 1987 , Section 2.

86 Ibid.

87 The Constitution of the Republic of the Philippines 1987: Article XIII, Section 18(1).

88 The United Nations Human Rights Committee. 2002/2. 'Consideration of Reports submitted by State Parties under Article 40 of the covenant: Second Periodic Report, the Philippines' 18 September, 74 , para 383 . 
CHRP's protection mandates are not limited to Filipinos in the Philippines, but that the CHRP's jurisdiction includes investigating all abuses of civil and political rights against Filipinos who live abroad. ${ }^{89}$

Subsequent resolutions have specified in more detail how the CHRP has to carry out its investigative functions. For example, Resolution No. A89 109 A (19 July 1989) empowers the CHRP to issue subpoena duces tecum or ad testificandum for the purpose of taking sworn statements or depositions conformably with procedures prescribed by the Revised Rules of Court; ${ }^{90}$ to cite or hold any person in direct or indirect contempt; to grant immunity from criminal prosecution; to call upon any government entity for assistance; and to appoint a counsel de officio for pauper litigants. ${ }^{91}$ Resolution No. A93 047 provides guidance on the procedures involved in the investigation, such as how and where to submit complaints. ${ }^{92}$ Importantly, according to this Resolution, staff of the CHRP who are in charge of conducting an investigation is enabled to work with the government prosecutor. ${ }^{93}$

Additionally, in 2012 the Commission adopted the Guidelines and Procedures in the Investigation and Monitoring of Human Rights Violations and Abuses, and the Provision of CHR Assistance. ${ }^{94}$ These guidelines make clear that the Commission understands its functions in terms of investigations broadly. These functions include conducting fact-finding missions, public inquiries and 'hearings on cases or incidents involving human rights violations'; issuing 'invitations, subpoenas, orders, or other processes requesting or directing any person to appear, attend and testify at the meeting, forum, conference, dialogue, public inquiry, or hearing conducted by the Commission'; and granting witnesses 'immunity from prosecution.' 95

The CHRP does not only focus on finding evidences from an investigation: it also has the task to protect witnesses, as provided by Article XIII, Section 18(8) of the 1987 Constitution. Res. No. A88 049 (19 Sept 1988) provides that the witness protection programme is offered to witnesses, victims and their family members to protect them from any form of harassment or threat. ${ }^{96}$ Witnesses

89 Ibid, 75 , para 384 .

9o Republic of the Philippines Supreme Court, Resolution on Revised Rules of Criminal Procedure (Rules 110-127, Revised Rules of Court) (3 October 2000) A.M. No. oo-5-03-SC.

91 Supra note 88,75 , para 385 .

92 Ibid, para 386.

93 Ibid.

94 The Commission on Human Rights of the Republic of the Philippines. 2014. 'The Guidelines and Procedures in the Investigation and Monitoring of Human Rights Violations and Abuses, and the Provision of CHR Assistance'. Retrieved 29 November 2019, https://pinoy filecabinet.files.wordpress.com/2014/07/chr-procedures-final_approved_8-31-2012.pdf.

95 Ibid.

96 Supra note 88,76 , para 390 . 
are provided shelter and subsistence allowances for the duration of the hearing, or for as long as it may be deemed necessary. ${ }^{97}$ Moreover, Article XIII, Section 18(3) of the Constitution states that the CHRP may provide 'appropriate legal measures for the protection of human rights of all persons within the Philippines, as well as Filipinos residing abroad, and provide for preventive measures and legal aid services to the underprivileged whose human rights have been violated or need protection'

With respect to judicial powers, the CHRP does not have the power to prosecute. However, to remedy the lack of such power, Resolution No. A93 047 (August 11 1993) provides that the CHRP investigator is tasked to coordinate with the government prosecutor and monitor the court proceedings. ${ }^{98}$ Also, the Department of Justice (DOJ) deputize CHRP lawyers to be able to file complaints directly with the prosecutor's office based on the results of their investigations. ${ }^{99}$ Interestingly, they can monitor the court proceedings, and provide medico-forensic services and the result of their investigations to other government offices, civil courts or other administrative bodies that have jurisdiction. ${ }^{100}$

In terms of the power to grant compensation to victims, Article XIII, Section 18(6) of the 1897 Constitution, and Res. No. A89 125 state that the CHRP has the power to grant financial aid to victims and their families. The following factors are relevant in determining the amount of compensation: (a) gravity of the HRV committed; (b) economic status and social history of the victims and their families; and, (c) expenses incurred as a result of the infliction of human rights violation. Approved claims can only be collected by the (a) victim; (b) parents, if the victim was single; (c) surviving spouse and the children of the victim in their concurring capacities, if the victim was married; or (d) brothers and sisters, if the victim is survived only by the latter. ${ }^{101}$

The categories of financial assistance available include: (a) survivor's benefit to heirs of victims, up to $\mathrm{PhP} 15,000$ per victim; (b) medical and hospitalization benefit not to exceed $\mathrm{PhP} 7,500$; (c) witness protection fund; (d) community assistance to evacuees; (e) special assistance to released prisoners and families involved in demolitions; and (f) legal and incidental expenses incurred in litigation. ${ }^{102}$

Another manifestation of the CHRP's duty to protect human rights comes in the form of visits to detention centers. Article XIII, Section 18(4) of the

$\begin{array}{ll}97 & \text { Ibid. } \\ 98 & \text { Ibid, 75, para } 386 . \\ 99 & \text { Ibid. } \\ 100 & \text { Ibid. } \\ 101 & \text { Ibid, 77, para } 393 . \\ 102 & \text { Ibid, 79, para } 396 .\end{array}$


Constitution provides that the CHRP is empowered to make unannounced visits to jails, prisons and detention facilities. This enables to directly assess whether conditions of detention centers and the treatment of prisoners therein are in compliance with human rights standards. A remarkable competency with respect to the human rights of those detained is the ability to represent prisoners or detainees and advocate for their release shall there no longer exist a legitimate ground to hold them in detention. ${ }^{103}$

To more clearly illustrate the protection powers of the CHRP, table 2 below summarizes its protection mandates. Even though the main objective of creating the CHRP was to prevent rampant human rights violations from ever occurring again in the country, the CHRP still lacks two protective powers which would have equipped it with a more significant capacity to deal with human rights violations: the power to make complaints to an inquiry officer, and the power to prosecute. Noticeably, these two powers are enshrined in the Paris Principles as only optional tasks of NHRIs.

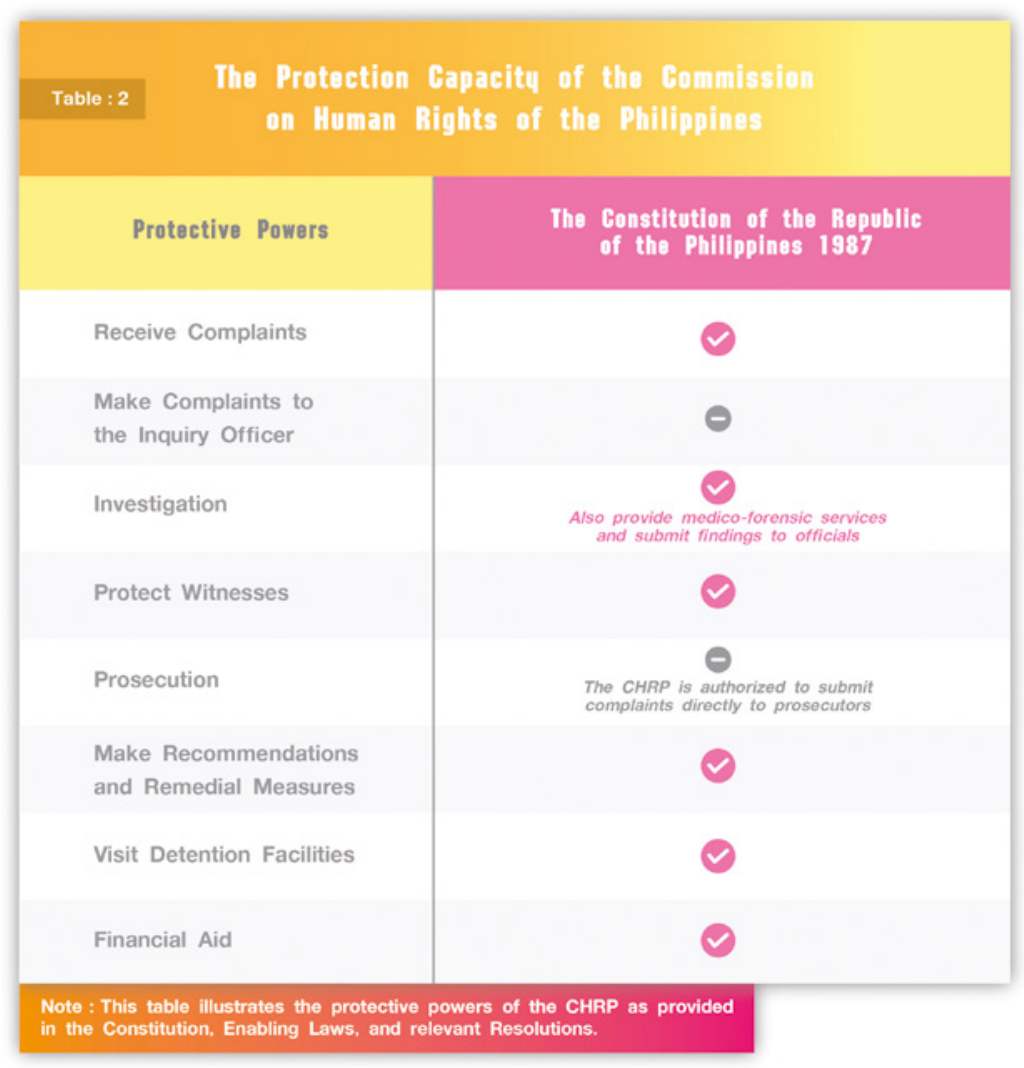

103 Ibid, para 398-400. 


\subsection{Thailand: Protective Mandates of the NHRCT}

The NHRCT was established in accordance with the Constitution of the Kingdom of Thailand, B.E. 2540 (1997). ${ }^{104}$ This NHRI was born out of the desire to reform state organs during Prime Minister Banharn Silpa-archa's tenure in 1995. ${ }^{105}$ At the time, the Committee on Political Reform had two ideas pertaining to the establishment of a NHRI. The first idea was to establish an NHRI as an independent institution, like the ones of the Philippines and South Africa. ${ }^{106}$ The rationale supporting this idea is that the government cannot interfere with an independent NHRI's work. ${ }^{107}$ The second idea suggested was for the NHRI to be a sub-department of the Ombudsmen. ${ }^{108}$ This idea was inspired by the NHRIs of some European countries, such as Spain and Denmark. ${ }^{109}$ The Committee submitted the plan with both ideas to the government, which however did not immediately make a decision. ${ }^{110}$

Instead, the government set up a specific working group to research on this issue and subsequently report to them on the difference between a NHRI that is independent and one that is under the Ombudsmen. ${ }^{111}$ The working group was to then make recommendations as to which option would be the most suitable for Thailand. On 18 July 1997, at the Meeting of the Constituent Assembly, many controversies surfaced: some members in the working group did not want to establish the NHRI anymore, some wanted to place it under the supervision of the Prime Minister. ${ }^{12}$

Nevertheless, those in the Committee and Assembly that supported an independent NHRI prevailed.113 They agreed on that the NHRI would be a national mechanism to protect the people's rights. Its establishment would also be consistent with the Universal Declaration of Human Rights and the International Covenant on Civil and Political Rights which Thailand had just ratified in January $1997 .{ }^{114}$ Finally, the Constitution of 1997 was passed on 11 October 1997 with provisions on the National Human Rights Commission of Thailand (NHRCT). ${ }^{115}$ The Constitution provided a time frame of two years to

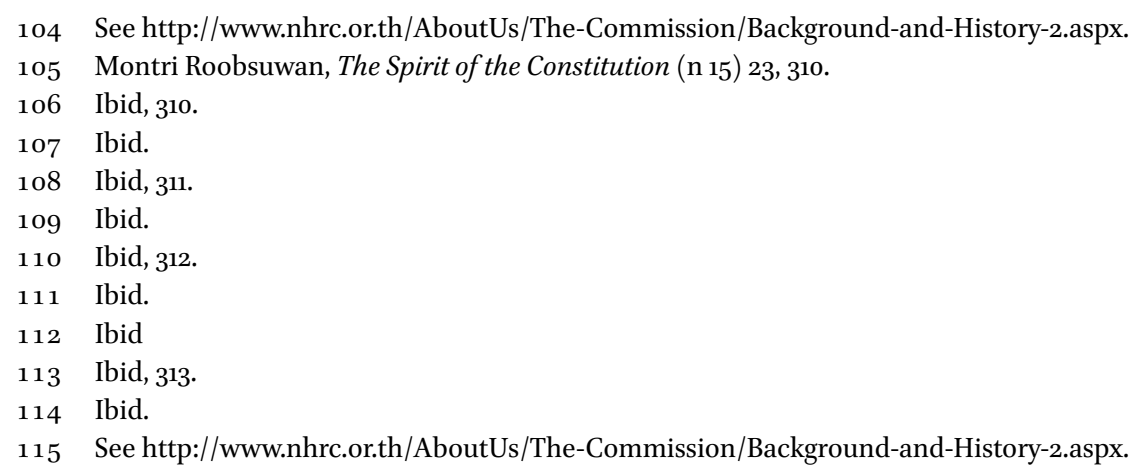


draft the National Human Rights Commission Act establishing the NHRCT. ${ }^{116}$ This Act was accordingly drafted and came into force in $1999 .{ }^{117}$

The NHRCT is therefore established by the Constitution from which it derives its mandate. However, as a result of the Constitution of Thailand being abolished and rewritten numerous times, the NHRCT's functions have been changed by virtue of three Constitutions, namely, the ones of 1997, 2007 and 2017. Thus, before examining the current mandates, the previous human rights protection powers provided to the NHRCT by the 1997 and 2007 Constitutions should be outlined for an understanding of how the NHRCT's protection capacity has been unstable and changed over time.

One may observe three eras of the NнRст. In the first era, the protective mandates of this N HRI could be found in the National Human Rights Commission Act of 1999 which was enacted to fulfil Article 334 of the 1997 Constitution. ${ }^{118}$ In terms of protective powers, the N HRCT had a power to receive complaints from individuals and NGOs. The Act used the words 'examination of human rights violations' which carry a milder note than 'investigation' in the Thai language, to mirror the term 'examination' which is used in the 1997 Constitution. ${ }^{119}$ However, further reading into the details of the mandate confirms that the NHRCT was empowered to establish a committee to investigate alleged violations. Section 26 of the 1999 National Human Rights Commission Act provides that the NHRCT, in conducting an examination of human rights violations, may appoint sub-officials to carry out investigations and make factual inquiries, hear responding statement of facts and evidence..$^{120}$

From this provision, it could be said that the examination power was intended to be used as a broad term, whereas investigative powers fell under that broad term. In conducting an examination, the NHRCT was - and still is empowered to mediate between the persons involved to reach an agreement, if it is possible, for compromise and redress of the human rights violation. ${ }^{121} \mathrm{In}$ addition, under the 1999 Act, when the examination is completed, and a commission or omission of acts which violate human rights is found, the NHRCT was empowered to require the perpetrators to stop violating human rights and perform their appropriate legal duties. It was also empowered to inform them

116 The Constitution of the Kingdom of Thailand (11 October 1997) Royal Gazette, Volume 114, Issue 55 Gor, Page 1, Part 8, Articles 199, 200, and 334.

117 See http://www.nhrc.or.th/AboutUs/The-Commission/Background-and-History-2.aspx.

118 The National Human Rights Commission Act of Thailand 1999 (25 November 1999) Royal Gazette, Volume 116, Issue 118 Gor, Pages 1-14.

119 Ibid, Section 18(2).

120 Ibid, Section 26.

121 Ibid, Section 27. 
about remedial measures for redressing human rights violations including the period for the implementation of such measures. ${ }^{122}$ If the violator has not implemented the remedial measures for redressing the human rights violation or has not completed the implementation without justifiable reasons, the NHRCT was empowered to report to the Prime Minister to order an implementation of the remedial measures. ${ }^{123}$

The second era of the NHRCT began with the Constitution of 2007, which granted to the NHRCT a more expansive mandate. In addition to all the protective powers already enshrined in the NHRCT Act 1999, the 2007 Constitution added adjudicatory-related mandates in Article 257 (2), (3), and (4). ${ }^{124}$ This Constitution granted the power of prosecution to the NHRCT, making it stronger in dealing with human rights violations. ${ }^{125}$ The NHRCT was empowered to refer the matter to the Constitutional Court in the case where it agrees with a complaint addressed by a complainant that any provision of law affects human rights, and to the Administrative Court in the case where it agrees with a complaint addressed by a complainant that a by-law, order or any other administrative act affects human rights. ${ }^{26}$ Significantly, this Constitution was the only legal authority ever since the NHRCT was established that offered a forceful protective power to the NHRCT in filing a lawsuit to the Court of Justice on behalf of the injured person when a request is made by the injured person and the NHRCT deems it appropriate to find a solution to the violation of human rights. ${ }^{127}$

The third and current era of the NHRCT began when all NHRCT mandates were changed by the newest Constitution of 2017, enacted under the military government's control. The 2017 Constitution, drafted by the committee set up by the military government who took power since 22 May 2014, provides the general features of the NHRCT in Article 247, supplanting that of the former 2007 Constitution. ${ }^{128}$ Moreover, the Organic Act on the National Human Rights Commission 2017 (hereinafter: Organic Act) was proclaimed seven months later, with its Article 3 totally abolishing the National Human Rights

\footnotetext{
122 Ibid, Section 28.

123 Ibid, Section 29.

124 The Constitution of the Kingdom of Thailand 2007 (24 August 2007) Royal Gazette Volume 124 Issue 47 Gor Pages 1-127, Article 257 (2), (3) and (4).

125 Ibid, Article 257(4).

126 Ibid, Article 257(2) and (3).

127 Ibid, Article 257(4).

128 The Constitution of the Kingdom of Thailand 2017 (6 April 2017) Royal Gazette Volume 134 Issue 40 Gor Pages 1-90.
} 
Commission Act of 1999. ${ }^{129}$ Since then, the powers and functions of the NHRCT are enshrined solely in the new Organic Act, and specifically in its Article 26.

Article 26 lists five tasks the NHRCT is mandated to do: to promptly find out and report the correct facts of human rights violations (Article 26(1)); to publish an assessment on the human rights situation (Article 26(2)); to propose measures to promote and protect human rights, as well as make proposals concerning the amendment of laws to be consistent with human rights principles (Article 26(3)); to promptly clarify and provide accurate information in the event there has been an inaccurate or unfair report of a human rights violation in Thailand (Article 26(4)); and to raise awareness among all sectors of the society on the importance of human rights (Article 26(5)).

The first observation that can be made is that these mandates weigh heavily on tasks of an advisory or human rights promotional nature. However, this is not to say that a protective function does not exist. In fact, Article 26(1) states that the NHRCT has the duty to examine and report on the correct facts regarding all cases of human rights violations. Also included in the competency under Article 26(1) is the power and duty to make recommendations to the concerned government agency or individual on three issues: preventive measures, remedial measures, and reparations to the victims.

The competency to examine and report on the correct facts regarding all cases of human rights violations under Article 26 is regulated in various other Articles of the Organic Act. For example, Article 27 provides that for the purposes of carrying out the functions in Article 26, the NHRCT shall also have the power and duty to encourage education and research on human rights, disseminate information about human rights, and assist victims of human rights violations. An interesting provision that governs the NHRCT's competency is Article 25 paragraph 2 of the Organic Act which reads that in the discharge of their duties, the NHRCT shall have regard to the culture, customs, and context of Thai society as well.

Most importantly, the protective competency of the NHRCT to examine and report on the correct facts regarding all cases of human rights violations is expounded in Part II of the Organic Act which is entitled 'Carrying out the Functions of the NHRCT'. In this Part, Article 34 provides that when an occurrence of a human rights violation becomes known to the NHRCT, the NHRCT shall, in a timely manner, conduct an examination so as to find the correct facts and make the truth become known. It must also study and make an analysis for the purposes of ascertaining the cause of the violation. Subsequent provisions

129 The National Human Rights Commission Act 2017: Organic Act. (12 December 2017) Royal Gazette, Volume 134, Issue 123 Gor, Pages 1-24. 
clarify and at the same time place impacts on this examination power. For example, Article 35 paragraph 1 clarifies that the NHRCT may employ any means or manner in conducting an examination. However, this is subject to the requirement that the means or manner of examination must not be too onerous to the relevant parties, and that the relevant parties must have a sufficient chance to explain and present evidence.

Moreover, paragraph 2 of Article 35 explicitly spells out the powers the NHRCT has in relation to conducting an examination. These include the power to request the appearance of individuals, to request submission of documents and evidence, and the power to enter into places. Significantly, these powers are subject to the requirement of necessity. According to Article 36 paragraph 1 and 2, if upon examination the NHRCT finds that a human rights violation is specific to an individual, it may instruct the concerned agency to remedy the violation within a suitable period of time which must be at least 60 days. If the agency, without good reason, fails to do so, Article 36 paragraph 4 gives the power to the NHRCT to notify the cabinet via a report.

In addition to the power to conduct an examination into human rights violations, Article 37 of the Organic Act provides that the NHRCT also has the power to make a complaint to the inquiry officer if the human rights violation also constitutes a criminal offense. To be able to exercise this power, it must be found that the victim is not able to make the complaint themselves. In this event, the NнRCT will be considered the victim under the Criminal Procedure Code. Finally, pursuant to Article 38 , if a Commissioner of the NHRCT sees that a human rights violation is occurring, if the violation needs to be addressed urgently, the Commissioner has the power to inform government agencies about the violation and ask them to help the victim to the extent that is possible under the competency of the informed agency. The law requires the informed agency to report on measures taken. Article 38 further states that in cases of unavoidable necessity, the NHRCT has the power to order a police officer to help.

The power to receive complaints, investigate and make complaints to an inquiry officer are the three protective powers which still exist. However, the powers of mediation and prosecution previously recognized in the NHRCT Act of 1999 and the 2007 Constitution are absent in this 2017 Act. Further, the NHRCT also does not have the power to visit detention facilities or the power to financially assist victims of human rights violations.

The protection capacity of the NHRCT pursuant to the different establishing laws can be summarized in table 3 below. As can be seen from the table, the NHRCT has gained only a few mandates to deal with human rights violations. It can only investigate and make recommendations, but after this process, 
there is no power to bring cases to the justice system such as through commencing prosecution or providing compensation to victims.

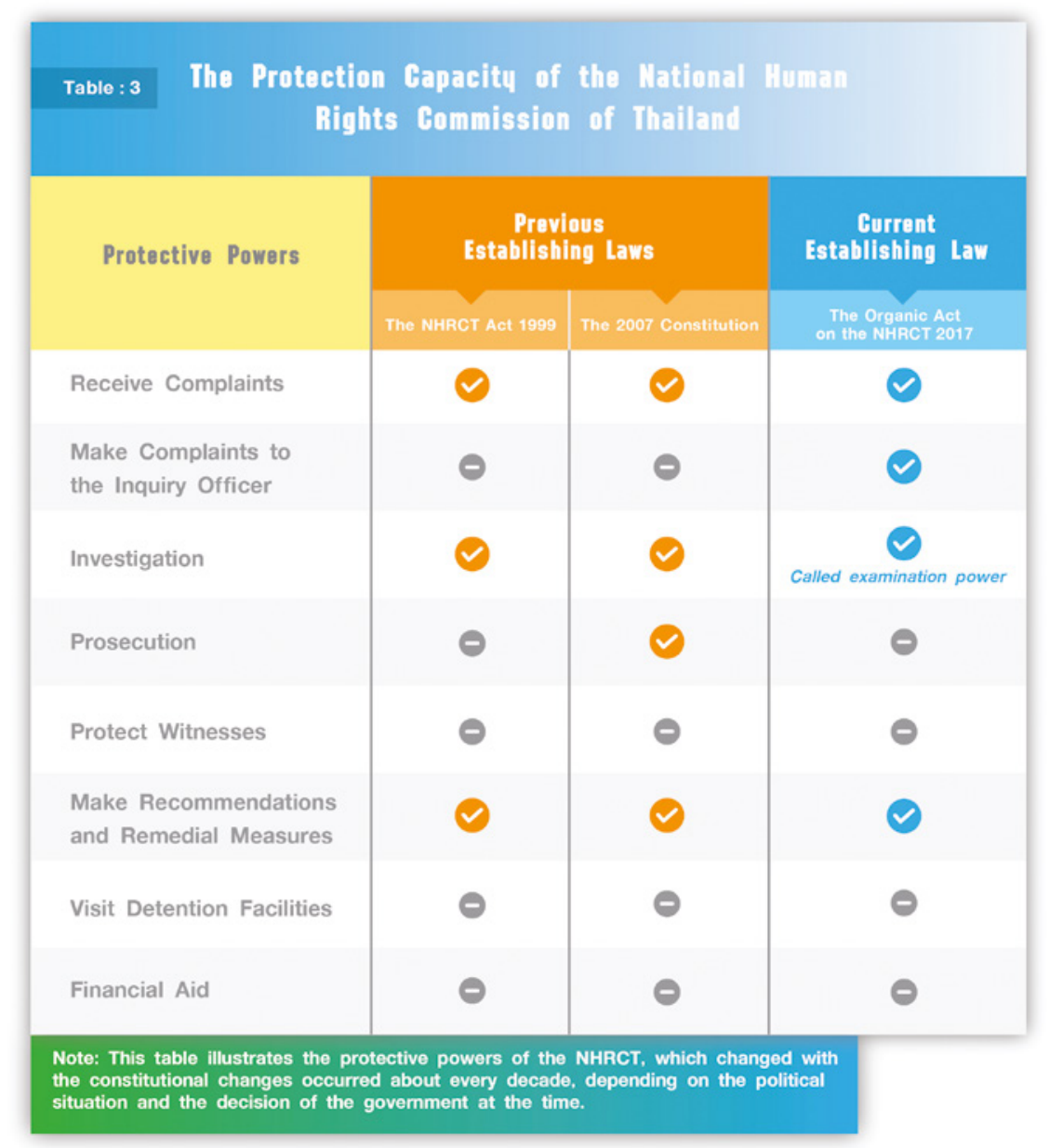

$5 \cdot 3$

A Comparative Analysis

5.3.1 A Comparison of the Factors Determining the Establishment of the CHRP and NHRCT

Before embarking in a comparison of the CHRP's and NHRCT's protection capacity, it seems opportune to briefly compare the factors that determined their establishment, since these factors had an important bearing on the scope and content of these two NHRIs' protection mandates. In the following paragraphs, the factors determining the establishment of the CHRP and NHRCT will be 
placed in the broader context of the literature on the factors determining the establishment of NHRIs in general.

Scholars have identified different factors determining the establishment of NHRIs. Following Gomez and Ramcharan, a few main rationales include: the need to ensure human rights protection in the immediate aftermath of significant violations; the consequence of a political revolution and transition to a more democratic regime; and international pressure and support. ${ }^{130}$ For example, as highlighted by Livingston and Murray, NHRIs in states like Northern Ireland, Spain, Latvia, and South Africa, were born after a domestic conflict and transition. ${ }^{131}$ Cameroon, Nigeria, Togo, and Mexico established their NHRIs in order to be seen to be doing something to address domestic human rights problems, after these countries came under the pressure to respond to allegations from international peers. ${ }^{132}$ On the contrary, in Australia, Canada, and France, a NHRI was established to underpin and cement other means of human rights protection. ${ }^{133}$

Reif notes that new NHRIs were established as states intended to democratize and/or become statutory members of an international community. ${ }^{134}$ Cardenas observes that NHRIs are 'created largely to satisfy international audiences; they are the result of state adaptation.'135 According to the International Council on Human Rights Policy, 'governments presiding over continuing serious violations of human rights calculate that establishing a commission will be a low-cost way of improving their international reputation.' ${ }^{136}$ States with poor human rights records are more enthusiastic to establish NHRIs even when doing so would be a self-restraining mechanism, and to recognize NHRIs' performances. This helps such States to avoid external critiques on human rights

130 James Gomez and Robin Ramcharan, "The "protection" capacity of National human rights institutions in Southeast Asia', Working Paper Series of The Southeast Asia Research Centre (SEARC) of the City University of Hong Kong 172 (2016) 3-8.

131 Stephen Livingstone and Rachel Murray, 'Evaluating the Effectiveness of National Human Rights Institutions: The Northern Ireland Human Rights Commission with Comparison from South Africa', University of Bristol and Queen's University Belfast, (2005) 35-37.

132 Ibid.

133 Ibid.

134 Linda C. Reif, 'Building Democratic institution: The Role of National Human Rights Institutions in Good Governance and Human Rights Protection', Harvard Human Rights Journal 13 (2000) 1-69.

135 Sonia Cardenas, 'Emerging Global Actors: The United Nations and National Human Rights Institutions', Global Governance 9 (2003) 23-42.

136 International Council on Human Rights Policy, Performance and Legitimacy: National Human Rights Institutions, (2004) 1. 
abuses and violations. ${ }^{137}$ This was the case for example in Malaysia and Indonesia, where arguably NHRIs were created to legitimize human rights violations committed by the State. ${ }^{138}$

The reasons for the NHRI's establishment in the Philippines match the first factors identified by Gomez and Ramcharan: the need to ensure human rights protection in the immediate aftermath of significant violations; the consequence of a political revolution and transition to a more democratic regime; and international pressure and support. ${ }^{139}$ As outlined above (Section 5.1), the endeavor of the Philippines in creating the CHRP was mainly driven by the reaction to the rampant violations suffered from under President Marcos' regime, and by the need to protect the rights of the Filipino people. The specific mandates provided by law to the CHRP confirm that this NHRI was really established to protect people's rights.

Unlike in the Philippines, in Thailand the awareness of the need to avert from human rights violations was not the main reason for the creation of a NHRI. Rather, the main reason for Thailand to establish its NHRI consisted in the intention of the ruling class to reform the state structure. This corresponds to the rationale outlined by Cardenas: state adaptation to satisfy international audiences. ${ }^{140}$

As a result, it can be seen that whereas in the Philippines the protection of human rights takes center stage in the establishing of the CHRP, in Thailand, it only played a supplementary role in determining the institutional design of the NHRI, whereby such concern added weight in favor of establishing an independent NHRI as opposed to a sub-department of the Ombudsmen.

Moreover, Article 334 of the 1997 Thai Constitution provided a two-year timeframe for completing the Act establishing the NнRCT. This is another significant point, which evidences that establishing the NHRCT was not an urgent agenda for Thailand. This lack of urgency is different from the situation in the Philippines where the NHRI was established promptly after the fall of the dictatorship. The 1987 Constitution of the Philippines was approved by ratification by the people on 2 February 1987. Three months later, on 5 May 1987, the CHRP was established. It can be argued that the objective to escape the dictatorship regime and the related human rights violations in the Philippines accelerated the creation of its NHRI.

137 Sonia Cardenas, Chains of Justice: The Global Rise of State Institutions for Human Rights (Philadelphia, University of Pennsylvania Press, 2014) 55-73.

138 Ken Marijtje Prahari Setiawan, Promoting human rights (n 10).

139 James Gomez and Robin Ramcharan, "The "protection" capacity of National human rights institutions in Southeast Asia' (n 137) 8.

140 Sonia Cardenas, Chains of Justice (n 144) 55-73. 
Our comparison of the factors determining the establishment of the CHRP and NHRCT, from the background of the description of the mandates of these two NHRIs included in Sections 5.1 and 5.2 of this paper, confirms that the reasons of establishing NHRIs reflect their performances, exact purposes, and protective mandates to deal with human rights cases. We argue that a NHRI whose primary reason of establishment was to really safeguard peoples' rights from massive human rights violations caused by a previous dictatorship regime like the CHRP has more stable and stronger protective mandates than a NHRI established for other reasons such as the NHRCT.

\subsubsection{A Comparison of the CHRP and NHRCT Protection Capacity}

The CHRP and NHRCT bear significant differences both in their protective mandates and in the stability of the legal basis from which the mandates are derived. On the one hand, the Philippines - as described in Section 5.1 established and amended specific laws to support the mandates of its NHRI, whereby none of the main protective functions enumerated by the Paris Principles has been withdrawn or eliminated afterwards. In Thailand on the other hand, different Constitutions under different governments have granted varying degrees of protection mandates to the NHRCT, reflecting the origin of the Thai NHRI-a product to suit the will of the ruling government. Thus, the CHRP evidently has more stable mandates than the NHRCT. This is one factor that impacts on the performance of a NHRI to deal with human rights cases because if the NHRI's mandates changes overtime like in Thailand, the performances become slower and the NHRI proves less effective to deal with human rights cases.

Moreover, the CHRP has more protective mandates which a NHRI should hold than the N нRст. Indeed, when comparing the competencies of the CHRP and the NHRCT, a number of differences can be observed:

Firstly, both the Philippine and Thai NHRIs can receive complaints of human rights violations. Even in absence of a complaint, both N HRIs can also act upon the knowledge of human rights violations on their own initiative. However, there is a difference: for the CHRP such action upon knowledge of a human rights violation in the context of the CHRP is called an 'investigation', whereas in Thailand the term 'to conduct an examination', which connotes a milder tone, has been adopted instead.

Secondly, with respect to the powers derivative from the power to investigate or conduct examinations, the CHRP's powers are more extensive. The NHRCT Organic Act of 2017, in regulating the NHRCT's examination powers, only considers powers which are already inherent in the normal course of the fact-finding activity. As mentioned in Section 5.2 above, the Organic Act 
provides that in the exercise of their examination powers, the NHRCT may request the appearance of persons, and the submission of evidence. It can be said that the provisions on these inherent powers are merely a clarification, or exemplification of what the NHRCT may do.

Thirdly, Article 36 paragraph 4 of the Organic Act provides that after examining, if the government agencies who are violators do not comply with the NHRCT's request to stop the violations and/or take responsibility for their violations and compensate the victims, the NHRCT may report these issues to the cabinet. In this sense, it can be observed that if the cabinet ignores or takes the side of the violating agencies, there is no provision or further step for the NHRCT to help victims which means that the cases might not be fairly resolved, and victims might not be properly compensated. In the Philippines, on the other hand, Section 18(6) of the Constitution states that the CHRP can directly provide financial aid for victims after having investigated and found cases of human rights violations. This is a significant mandate in respect to which we argue the CHRP should be an example for the NHRCT to learn from. It is very important that the violations can be at least redressed to satisfy the victims, which should be protected and compensated without any governmental approval.

Fourthly, the CHRP has a more extensive list of capabilities in terms of witness protection. What the CHRP is allowed to do when it investigates alleged human rights violations extends beyond the obvious task of finding facts from relevant parties. It has to be recalled that the CHRP can offer witness protection while investigations are being conducted, they can provide legal and even medico-forensic assistance to victims. On the contrary, no power of this kind is given to the NHRCT. It can therefore be said that the competencies of the CHRP are truly based upon all needs of a victim of human rights violations in the course of an investigation. As such, the CHRP's investigative competencies are more extensive and comprehensive than the competency to conduct examinations in the case of the NHRCT.

Fifthly, in terms of facilitating the access of victims to the judicial process, the NHRCT, on the one hand, is able to make a complaint to an inquiry official when the victim cannot do so themselves - if a human rights violation against the victim also constitutes a crime. Pursuant to the Thai Criminal Procedure Code, the inquiry official will then have to investigate the case, and later send the files to a prosecutor. The files will include an opinion by the inquiry official as to whether the official recommends the case to be prosecuted or not. The prosecutor will review the files and the inquiry official's recommendations. The decision to prosecute or not will be subject to the prosecutor's discretion. The CHRP, on the other hand, is endowed with the power to make a complaint 
directly to a prosecutor, bypassing the police, which is mentioned in Resolution No. A93 047. This significant difference shows that the CHRP facilitates a more direct access of human rights victims to the justice system and to judicial procedures than the NHRCT. The CHRP may directly access the prosecutorial process which is more helpful for victims where the NHRCT only has the power to communicate with the police, a process which can be slow, reluctant, and can cause victims to be subject to an unfair legal process in many occasions and ways. Also in this regard, Thailand should learn from the Philippines.

Sixthly, the perhaps greatest difference between the CHRP and NHRCT can be observed with respect to financial assistance. On the one hand, the CHRP's ability to provide financial assistance once again testifies that the real needs of a victim of human rights violation have been taken into account and reflected in the CHRP's mandate. The legal bases for this provision of financial assistance - Section 18(6) of the 1987 Constitution, and Res. No. A89 125 form a significant part of the CHRP's mandate. There are concrete guidelines on the mandate and corresponding amounts of remuneration for victims of human rights violations. ${ }^{141}$ On the other hand, in Thailand, the NHRCT can only provide remuneration to cover the cost of transportation fees for persons travelling to give testimony which is provided in Article 35(3) of the Organic Act 2017. Thus also in this regard the CHRP has powers granted by law which can effectively help human rights victims. It would be extremely beneficial for other N HRIs such as the NHRCT to have these powers in order to help victims in a direct and timely manner without the need to wait for awards from court judgments, which could be uncertain and time-consuming.

Seventhly, in terms of prosecution and adjudication, we notice that neither NHRI has the ability to prosecute or adjudicate a case of alleged human rights violation. However, unlike the NHRCT, the CHRP can visit detention facilities, which is an important task because in such facilities human rights violations, such as torture and inhuman treatment, are likely to happen. Lastly, and rather notably, the NHRCT's exercise of its functions is subject to principles of necessity, and peculiarly, the culture, customs, and context of Thailand. On the contrary, the CHRP is not bound by such considerations in carrying out its functions.

The differences in the two NHRIs' protective powers are briefly summarized in the table below.

It can be said that the protective powers of the CHRP are more established, extensive, and comprehensive than the ones of the NнRCT. This difference is

141 ChrP Resolution No. A89-125 and No. A96-o6o. 


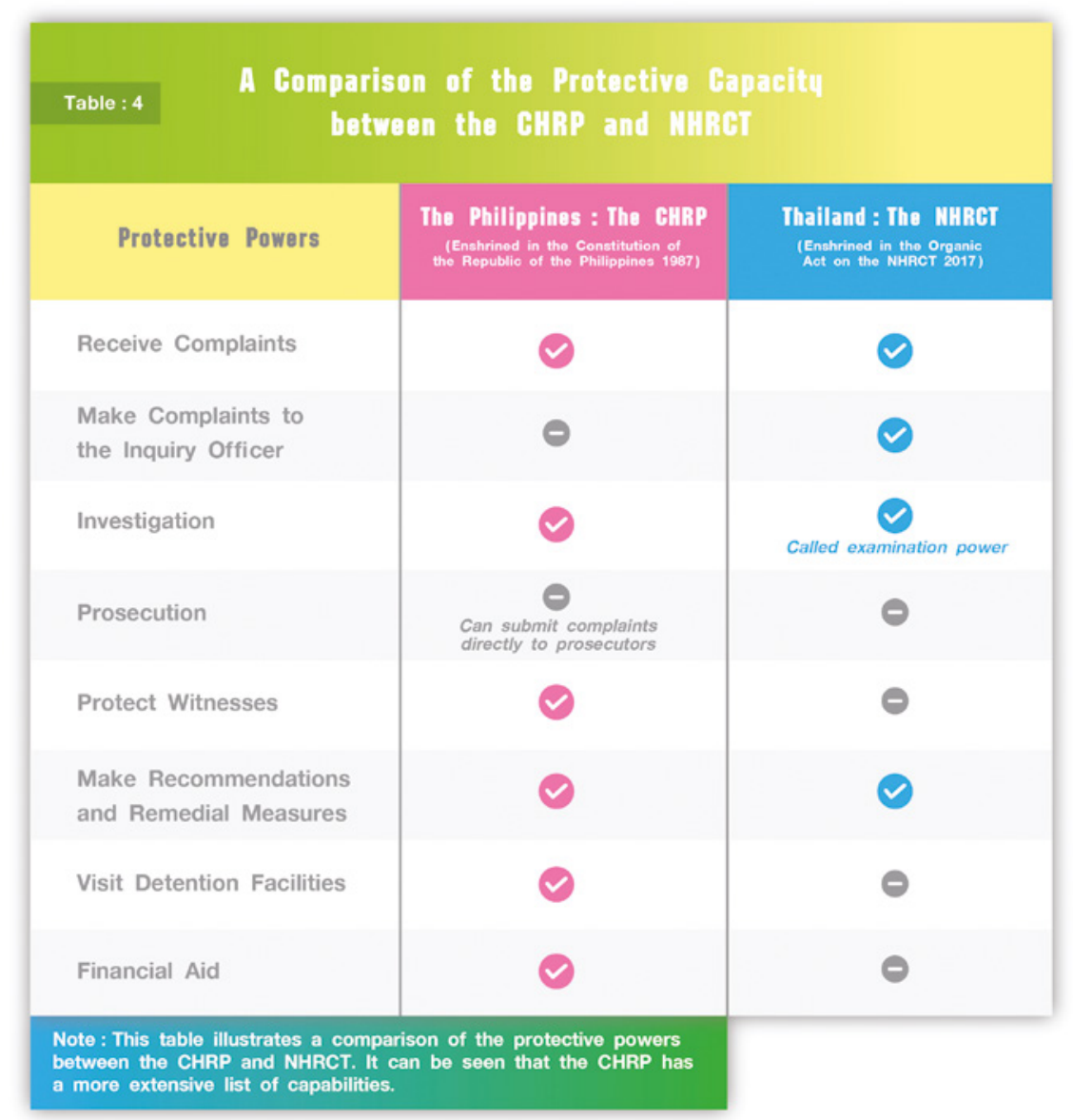

arguably due both to the different reasons of establishment of the two institutions, and to the different degrees of stability of the two Constitutions. Deliberately, many Resolutions refine and provide guidelines on the particularities of CHRP's protective powers. The same cannot be said for the NHRCT. The protective functions of the Thai NHRI are unstable in comparison to the one of the Philippines. The above comparison has shown that the CHRP is better equipped with tools to more effectively deal with human rights violations than the NHRCT. The CHRP has almost all of the protective functions enumerated by the Paris Principles which NHRIs should have to help victims. The NHRCT lacks a few significant functions even though it meets the Paris Principles' minimum standard. Arguably, if the NHRCT had the same protective mandates as the CHRP, its protection capacity would be much greater. 


\subsection{Approaches Proposed in the Literature}

Scholars have noted that governments are the main source of explicit impacts on the protection capacity of NHRIs. ${ }^{142}$ NHRIs in politically unstable states will risk not being able to carry out their mandates properly, because their sustenance is tied to the government: they can be subject to aggressive intervention by the government or its apparatus. ${ }^{143}$

The government is also the main attributor who underpins a NHRI's legitimacy and credibility. NHRIs are able to work effectively if governments accept and respect human rights, no longer see human rights as merely negative obligations, but look at human rights as positive duties. ${ }^{144}$

Furthermore, scholarly work has shed light onto the manners by which governments can set restrictions to NHRIs' protective capacity. A prime example is India. As Smith notes, the Indian government exempted violations of human rights committed by the armed forces from the National Human Rights Commission (N HRC) investigatory powers, thereby building in structural limitations to 'the independence of the institution in protecting the people against the government and/or its agencies'. ${ }^{145}$

A question often raised is whether it is possible for NHRIs to be really independent of the government. NHRIs' independence is at the very heart of the concern on their effective performance, and also marks the difficulty in protecting human rights. ${ }^{146}$ NHRIs' autonomy from the government allows them to investigate the government and its actors with respect to the commission of human rights violations whereas being under government control can jeopardize their capabilities. ${ }^{147}$ The ability of NHRIs to undertake investigations autonomously, to demand the production of written documentation, to compel answers to questions, to threaten with court proceedings if a person or organization is not cooperative, to publish the outcome of the investigation, and to access prisons and places of detention are perhaps among the most

\footnotetext{
142 Gauthier de Beco and Rachel Murray, A Commentary on the Paris Principles on National Human Rights Institutions (n 2).

143 Jonathan Liljeblad, 'The Efficacy of National Human Rights Institutions Seen in Context: Lessons from the Myanmar National Human Rights Commission', Yale Human Rights and Development Journal 19(1) (2017) 95-132.

144 Mary Robinson. 2003. From Rhetoric to Reality: Making Human Rights Work, special lecture at the London School of Economics and Political Sciences. 23 October. Retrieved 29 November 2019, https://digital.library.lse.ac.uk/objects/lse:wan437vas.

145 Anne Smith, 'The Unique Position of National Human Rights Institutions' (n 1) 917.

146 Ibid, 912.

147 Ibid.
} 
important indicators of their operational independence, which is also deliberated in the Paris Principles. ${ }^{148}$

Smith remarks that it may be difficult to assess whether NHRIs work independently or not because they are funded and appointed by the government. ${ }^{149}$ The issue of financing is one of the vital matters which should guarantee NHRIs' independence from governmental control. In India, the fiscal autonomy of the Jammu and Kashmir State Human Rights Commission (s H RC) is reliant upon the Financial Department of State, therefore, the SHRC is reduced to a dependent extension of the government. ${ }^{150}$ Moving on to the African continent, in Chad, and Togo, governments have purposefully reduced the budgets of the NHRIs, when these exercised their independent right to grumble their respective governments. ${ }^{151}$ In Cameroon, the NHRI's funding was radically reduced for two years after it launched a confidential report with condemnations on its government abuses in the situation of state of emergency in the North-West Province in $1992 .{ }^{152}$ In Zambia, due to shortages in funding, the NHRI lost government premises which had been promised to it after voicing complaints on the torture of military coup detainees in 1996.153

\subsection{This Paper's Approach to the Impacts on NHRIs' Performances}

This paper focuses on the impacts on the performances of NHRIs which can be enhanced or limited by governments. We agree with scholars like Gauthier de Beco and Jonathan Liljeblad, who pointed out that governments are the main source of explicit impacts to the performances of NHRIs. Section 7 of this paper comparatively analyses how the governments of the Philippines and Thailand have been impacting their NHRIs. This research highlights both similarities and differences in the manner by which both NHRIs have been impacted by their governments.

This paper also shares Anne Smith's view that independence is at the very heart of the concern on an NHRI's effective performance. Our research clarifies

\footnotetext{
148 Ibid, 914. See also National Institutions for the Promotion and Protection of Human Rights, adopted 4 March 1994, G.A. Res. 48/134, U.N. GAOR, 48th Sess., U.N. Doc. A/Res/48/ 134 (1994).

149 Anne Smith, 'The Unique Position of National Human Rights Institutions' (n 1) 918.

150 Terry Collingsworth, "The Key Human Rights Challenge: Developing Enforcement Mechanisms', Harvard Human Rights Journal 15 (2002)188-190. See also Vijayashri Sripati, 'India's National Human Rights Commission: A Shackled Commission?', Boston University International Law Journal 18 (2000) 15 .

151 Binaifer Nowrojee, Protectors or pretenders? Government human rights commissions in Africa (New York: Human Rights Watch, 2001) 132-149, 332-351.

152 Ibid, 112-131.

153 Ibid, $376-392$.
} 
that despite the NHRIs of the Philippines and Thailand have an independent status as guaranteed by their national constitutions, the governments of both countries are still able to limit their NHRIs in many ways. This confirms that an NHRI's independence must be scrutinized not only in legal terms but also from the viewpoint of political practice.

\section{7 \\ Impacts on the Performances of the CHRP and NHRCT}

\subsection{The Philippines: the CHRP}

The present section of this paper will focus on the impacts on the CHRP's performance in the exercise of their mandates since President Duterte took office in 2016. After declaring the policy of war on drugs, his rhetoric against human rights has been well documented. The impacts on the performance of the CHRP are mainly caused by Duterte and his administration supporting and complying with his policy of war on drugs. Interestingly, almost all of these impacts have a merely political nature and do not directly involve legal powers. The main weapons used to interfere with the CHRP's activity were anti-human rights rhetoric, threats, and budget cuts. The reason why Duterte so far has not been able to affect the CHRP by legal actions is because the CHRP's mandates have a strong and stable legal basis in the Constitution of 1987, which cannot be changed by simple political majority. The Constitution may only be changed by a Costituent Assembly, or a People's Initiative, or a constitutional convention. According to Article XVII, Section 3 of the Constitution, the Congress may, by a vote of two-thirds of all its members, call a constitutional convention, or by a majority vote of all its members, submit to the electorate the question of calling such a convention. ${ }^{154}$ Thus it is very difficult to amend the mandates of the CHRP. Therefore, the impacts to the CHRP's performance set by the Philippine's government so far, and analyzed in this research, pertain to Duterte's political actions rather than legal actions.

The first weapon which Duterte used to limit the CHRP's performances is his rhetoric against human rights. For example, he publicly supports acts that violate human rights, namely, summary killings against alleged drug dealers and users. United Nations High Commissioner Zeid noted that the President's repeated calls for the police, military and the general public to engage in a 'war on drugs', bringing people in 'dead or alive', has fostered an environment of

154 Dante Gatmaytan-Magno, 'Changing Constitutions: Judicial Review and Redemption in the Philippines', UCLA Pacific Basin Law Journal 25 (2007) 3-4. 
alarming impunity and violence. ${ }^{155}$ This environment, coupled with the unpopular opinion of human rights closes the political space in which the CHRP works.

Raymund Rosuelo, Chief of the Research, Documentation, and Resources Division of the Commission on Human Rights of the Philippines remarked that currently, ' $(t)$ here is an automatic tendency for many citizens to label the work of the CHRP as being against progress' and that the CHRP's defence of criminals 'impacts the acceptance of the CHRP.'156 He added that the CHRP's 'biggest challenge lies in mobilizing support form a majority of the population to subscribe to the concept of human rights in the age of populist governance.'157

In the second example, Duterte called CHRP chairman and human rights defender, Chito Gascon, a 'pedophile' on national television, because of Chito's focus on the killing of teenagers in the government's bloody war on drugs. ${ }^{158}$ The reason for such a defamation of the CHRP chairman was that since the policy of war on drugs was launched, resulting in severe human rights violations, the CHRP obviously has been critical of this issue. By proclaiming that the CHRP chairman is fixated with young males, Duterte denigrated him publicly. The people of the Philippines take Duterte's rhetoric seriously, because of the appeal of the 'strongman' in Filipino culture. Chito Gascon himself explains it:

The appeal of the strongman is not new and has enticed adherents throughout history. Their proposition has always been simple and strangely effective. They pose a false choice, presenting - in a complex society of competing interests - an alternative of greater safety, security, and stability, in exchange for diminished freedoms. This false and even dystopian dichotomy has regained some currency by feeding upon growing public frustration with governments' inability to make democracy work for all. And that is how strongmen—perceived to be decisive, armed

155 The United Nations Human Rights Office of the High Commissioner. 2016. 'Zeid urges investigation into Philippines president's claim to have killed three people' 20 December. Retrieved 29 November 2019, https://ohchr.org/EN/NewsEvents/Pages/DisplayNews .aspx?NewsID=21052\&LangID=E.

${ }_{15} 6$ Raymund Rosuelo, Chief of the Research, Documentation, and Resources Division of the Commission on Human Rights of the Philippines. (October 2019). Telephone interview.

157 Ibid.

$15^{8}$ The Conversation. 2018. 'The brutal personal costs of the Philippines' human rights abuses.' 2 August. Retrieved 29 November 2019, http://theconversation.com/the-brutal -personal-costs-of-the-philippines-human-rights-abuses-100694. 
with populist rhetoric in a 'post-truth' world, and ready to cut democratic corners-rise to power. ${ }^{159}$

Ramon Casiple, a political analyst, remarked that despite criticism from opposition politicians and international organizations, Duterte remains popular in the Philippines. ${ }^{160}$ Being the strongman in his country, Duterte with his rhetoric and actions can be said to contribute to diminish the CHRP's effectiveness. Duterte's rhetoric imposes on the public the opinion that human rights defenders are enemies of the state, that human rights stifle progress and undermine security, and that human rights causes are insignificant and to be ignored.

The second weapon which Duterte used to limit the CHRP is his attempt to undermine it financially and institutionally. For what concerns the financial undermining, Duterte remarked that the CHRP deserves a low budget because it is 'useless' and always protects criminals' rights. ${ }^{161}$ In 2018, the CHRP requested a budget of 1.72 billion pesos ( $\mathrm{PhP})$, but the government proposed less than half of that. ${ }^{162}$ In the end, the Commission was allotted PhP 689,706 million (about 12,000 Euro) in the National Expenditure Program for the fiscal year of 2019. This is only half of the originally proposed $\mathrm{PhP} 1.176$ billion budget. ${ }^{163}$ The budget requires the Senate's approval before it becomes final but it passed because Duterte holds a majority in both chambers of the house. ${ }^{164}$ It has been noted that Duterte's lobbying has an impact on Congress whereby the more passionately he defends the passage of bills, the more likely they will be passed into laws. ${ }^{165}$ As such, it could be said that Duterte has influence over legislative instruments that effect the CHRP's mandate and fiscal autonomy.

159 Chito Gascon, 2018. 'What the Philippines Tells Us About the Broken Promises of Human Rights.' Time, 30 May. Retrieved 29 November 2019, http://time.com/5294301/what-the -philippines-tells-us-about-the-broken-promises-of-human-rights/.

160 ABS-CBN News. 2018. 'Two years on, Duterte remains popular among Filipinos: analyst' 30 June. Retrieved 29 November 2019, https://news.abs-cbn.com/focus/o6/30/18/two-years -on-duterte-remains-popular-among-filipinos-analyst.

161 Harriet Agerholm, 2017. 'Philippines cuts its human rights budget to £15.' Independent, 13 September. Retrieved 29 November 2019, https://www.independent.co.uk/news/world/ asia/philippines-human-rights-budget-cut-rodrigo-duterte-war-drugs-isis -marawi-a7944086.html.

162 Ibid.

163 Commission on Human Rights of the Republic of the Philippines. 2018. 'House of Reps pitch for higher $\mathrm{CHR}$ funding during plenary debates', 25 September. Retrieved 29 November 2019, http://chr.gov.ph/hor-pitch-for-higher-chr-funding-during-plenary-debates/.

164 Harriet Agerholm, 'Philippines cuts its human rights budget to $£_{15}$ ' (n 161).

165 Mara Cepeda, 2018. 'Duterte didn't lobby enough, only 5 of 18 priority bills became laws' Rappler, 22 July. Retrieved 29 November 2019, https://www.rappler.com/nation/206211 -duterte-congress-priority-bills-second-year. 
For what concerns the institutional undermining, the President on numerous occasions has threatened to abolish the CHRP. For example, in a press conference after his second State of the Nation (Sona) at the House of Representatives in Quezon City, he said: 'And when the time comes, Commission on Human Rights, you are better abolished.'166 Also, he insisted that the police or any officials working to support his war-on-drugs policy will not be investigated by the CHRP without his consent:

I will not allow my men to go there to be investigated. Human Rights Commission, you address your request through me because the Armed Forces is under me and the police is under me $(. . .)^{167}$

Lastly, the President cut the CHRP's network of cooperation, both international and domestically. On the international front, he withdrew the Philippines from the International Criminal Court. In February 2018, the International Criminal Court (ICC), as announced by the Office of the Prosecutor, began a preliminary investigation into the situation of the 'war on drugs' campaign launched by the Government of the Philippines. ${ }^{168}$ As such, the CHRP can be involved with respect to the ICC's investigation into the alleged extrajudicial killings. However, Duterte's public statement dissuading the police from cooperating in human rights investigations, particularly with respect to the alleged extrajudicial killings in the war on drugs, disconnects networks of cooperation between domestic and international organizations that are able to support the CHRP's work. ${ }^{169}$

He also threatened to arrest the Prosecutor of the ICC if she conducts investigations in the Philippines and told the police to not cooperate 'when it comes to human rights, whoever rapporteur it is.' ${ }^{170}$ These public statements, in

166 https://newsinfo.inquirer.net/917250/duterte-threatens-to-abolish-chr.

167 Ibid.

168 Martin Petty, 2018. 'Hague court opens examination into Philippines drugs war deaths', Reuters, 8 February. Retrieved 29 November 2019, https://www.reuters.com/article/usphilippines-drugs-icct/hague-court-opens-examination-into-philippines-drugs-wardeaths-idUSKBN1FSoKU; See also The International Criminal Court. 2018. 'Statement of the Prosecutor of the International Criminal Court, Fatou Bensouda, on opening Preliminary Examinations into the situations in the Philippines and in Venezuela' 8 February. Retrieved 29 November 2019, https://www.icc-cpi.int/Pages/item.aspx?name=180208-otp -stat.

169 The Guardian. 2018. 'Rodrigo Duterte tells police not to cooperate in drug war investigation' 2 March. Retrieved 29 November 2019, https://www.theguardian.com/world/2018/ mar/o2/rodrigo-duterte-tells-police-not-to-cooperate-in-drug-war-investigation.

170 Frederic Burnand, 2018. 'World must act on a litany of crimes, says outgoing human rights commissioner' JUSTICEINFO.NET, 8 March. Retrieved 29 November 2019, https://www 
addition to being hurtful, have the effect of belittling figures of human rights defenders, and the causes and values for which they stand as being insignificant and to be ignored. Finally, the Philippine government transmitted its notice of withdrawal to the office of the UN Secretary-General in New York, formalizing the announcement of President Duterte on 14 March 2018, and the withdrawal took effect on 17 March 2019. ${ }^{171}$ This withdrawal has a negative impact as it limits the temporal scope of the CHRP's cooperation with the ICC. In other words, although the CHRP can continue to cooperate with the ICC even after March 2019, such cooperation by, for example, supporting information and evidences, will most likely be only with respect to the situation of the extrajudicial killings that happened before the withdrawal of the Philippines from the Rome Statute took effect in March 2019, because only the events happening within that period will still fall within the jurisdiction of the ICC.

On the domestic front, the CHRP's work on facilitating the administration of justice in the case of extrajudicial killings has been made difficult by the authorities carrying out Duterte's policy. First, the police changed the language which they used to identify deaths that seem connected to the war on drugs. Having previously referred to those deaths as deaths under investigation, the police now use the term homicide to designate that there are no longer any cases under investigation, that they have finished conducting investigations and have concluded that they were a result of homicides. ${ }^{172}$ By doing so, the police do not have to report any new cases of killings of journalists and activists, because the police consider the cases solved.

Second, the police have been accused of covering up the extrajudicial killings by planting evidence, tampering with crime scenes, and unlawfully disposing of bodies of drug suspects, among others. These acts allegedly allowed the police to resolve the cases as being legitimate. ${ }^{173}$ Third, the police simply did not cooperate and refused to hand in even the information available to them that was related to the alleged extra-judicial killings. The unwillingness of the government to cooperate in independent investigations, and the police's

.justiceinfo.net/en/tribunals/national-tribunals/36642-world-must-act-on-a-litany-of -crimes-says-outgoing-human-rights-commissioner.html.

171 Lian Buan and Jodesz Gavilan, 2019. 'Duterte throws decade-long fight for the International Criminal Court' Rappler, 13 March. Retrieved 29 November 2019, https://www .rappler.com/newsbreak/in-depth/225454-philippines-duterte-withdrawal-international -criminal-court.

172 Amnesty International. 2019. "They just kill' ongoing extrajudicial executions and other violations in the Philippines' 'war on drugs', 10. Retrieved 29 November 2019, https://www .amnesty.org/download/Documents/ASA3505782019ENGLISH.PDF.

173 Ibid. 23. 
withholding of information, make it difficult for the CHRP to work and continue their own investigations. ${ }^{174}$

It can also be argued that the climate of fear and impunity brought about by Duterte's rhetoric against human rights has caused the families of victims to be fearful and not come forward to be involved with CHRP's investigations. This was indeed reported by the CHRP who cited a number of cases where the investigation remains unresolved due to non-cooperation from the victim's families. Raymund Rosuelo confirms that the CHRP started to face impacts in dealing with human rights violations after 2016 which is the year that President Duterte came into power. ${ }^{175}$ He notes that the number of resolved cases has been decreasing, especially the cases involving governmental actions and policies such as extrajudicial killing. ${ }^{176}$

\subsection{Thailand: The NHRCT}

Thailand has been ruled by the military government since 22 May 2014. After the 2019 general elections, the new Parliament elected the junta chief Prayuth Chan-ocha as Prime Minister. Thus, the same military government now continues in the form of a civilian government to maintain control over the security forces and all governmental institutions. The military junta, called the National Council for Peace and Order (NCPO), was formally dissolved when the new cabinet swore in on 16 July 2019, but de facto continues its previous work under new forms and names. ${ }^{177}$

The NCPO's vow to stamp out corruption and return the country to democratic rule has been used to legitimize their powers in a variety of ways. In many cases, human rights abuses were perpetrated by government officials. Public discussion on the state of human rights and democracy have been blocked by authoritative laws. Sedition and computer-related crimes have been the main criminal charges, subjecting numerous activists and dissenters, who acted against the government through peaceful expression of their views, to arbitrary arrest, prosecution, and detention. ${ }^{178}$

174 Raymund Rosuelo, Chief of the Research, Documentation, and Resources Division of the Commission on Human Rights of the Philippines. (October 2019). Telephone interview.

175 Ibid.

176 Ibid.

177 Pithaya Pookaman, 2019. 'Thailand's Government a Junta by Any Other Name' Asiasentinel, 19 July. Retrieved 29 November 2019, https://www.asiasentinel.com/politics/ thailand-government-junta-by-any-other-name/.

178 Matichonweekly. 2017. 'Summary on the Human Rights Situation in Thailand for the Year 2019 through the Eyes of Human Rights Organizations both Thai and International' 28 December. Retrieved 29 November 2019, https://www.matichonweekly.com/in-depth/ article_72772. 
Apart from violating human rights, the Thai military government also took steps to undermine the NнRст. One of the first steps was the proposal of abolishing the NHRCT as such and make it to a sub-department of the Ombudsmen. ${ }^{179}$ Before 2017, the NHRCT was one of the Other Constitutional Organs empowered by the 2007 Constitution. During the drafting process of the 2017 Constitution operated by the junta-appointed Constitution Drafting Committee (CDC), there were plans to withdraw the NHRCT from the Constitution. ${ }^{180}$ This exemplifies the manner in which the government tried to impact the NHRCT's performance by proposing a fundamental change in the Commission's very structure: the proposal of merging it with another institution or even abolishing it.

Although the military government-appointed Constitution Drafting Committee failed to merge or abolish the NHRCT, other governmental agencies and the cabinet have succeeded in limiting the NHRCT's work. One of the manners by which governmental agencies and the cabinet have impacted the NHRCT's work is their blatant unresponsiveness. Interestingly, this unresponsiveness is made possible by the law: The government and its agencies can insist that the law merely provides that they shall have the power to receive information from the NHRCT, whereas further action to be taken by the government and its agencies has not been specified in the law. As mentioned under 5.2 above, according to Article 26(3) of the Organic Act 2017, the NHRCT has the power to recommend governmental agencies that violated people's rights to stop their actions. Article 36 of the same Act also provides that if upon examination the NHRCT finds that a human rights violation is committed by a governmental agency against a specific individual, it may instruct the concerned agency to remedy the violation within a suitable period of time which must be at least 60 days. ${ }^{181}$ If the agency, without good reason, fails to do so, the N HRCT may notify the cabinet. ${ }^{182}$ In reality, government agencies and the cabinet always ignore this process, and are not willing to come to any resolution.

This unresponsiveness which impacts the NHRCT's performance in dealing with human rights cases has been witnessed on numerous accounts and in varying degrees. For example, in the case of the 'Walk for Rights' protest, where demonstrators who requested the government to address problems about

\footnotetext{
179 MGR Online, 2015, 'Merging the NHRCT and the Ombudsmen-a Brewing Anger Waiting to Burn the NCPO' 4 March. Retrieved 29 November 2019, https://mgronline.com/daily/ detail/9580000038888.

180 Ibid.

181 The Organic Act of National Human Rights Commission of Thailand 2017, Article 36 para 4.

182 Ibid.
} 
distributing land for agricultural purposes were arrested and coerced to end the demonstration, the NHRCT issued a statement urging the government to investigate the conduct of the officials who carried out the arrest and coercion. ${ }^{183}$ The government issued a resolution stating that human rights protesters will receive the same treatment as any civilian: If they violate the law they will be sanctioned. The resolution stressed the need to balance the fight for human rights with the protection of public interest, making reference to the sensitive nature of the subject at hand. ${ }^{184}$ As the subject matter of this protest is not too political, the government will not be completely unresponsive. As a matter of fact, it even stated in the resolution that it has consulted the Ministry of Justice and is trying to amend legislation on agricultural land distribution.

A higher degree of unresponsiveness is seen with respect to complaints on political cases which directly affect the government's political image. The case which exemplifies this level of unresponsiveness is the 'We Move' case. Here, a group of people called 'We Move' organized a forum to discuss political issues and the drafting of the new Constitution of Thailand under the military government in 2016. ${ }^{185}$ Despite being a peaceful event, governmental security units arrived at the venue to prevent it from happening. This case was brought up by the NнRCт. ${ }^{186}$ The government responded that the officials acted under the law. The relevant law consisted in an announcement proclaimed by the military governmental officials themselves in their capacity as NCPO. ${ }^{187}$ This

183 Isranews Agency. 2018. 'Fear from being Harassed and Sued to Silence! NHRCT Prepares 3 Proposals to the Prayuth Government to Solve Human Rights Violations'14 October. Retrieved 29 November 2019, https://www.isranews.org/isranews-news/70291-isranews $-70291 . h t m l$.

184 The Secretariat of the Cabinet. 2018. 'Cabinet Resolution on the Results of Deliberation of Proposals on Human Rights Promotion and Protection (Regarding the Alleged Harassment of Human Rights Defender by Government Officials), 2 October. Retrieved 29 November 2019, http://www.cabinet.soc.go.th/soc/Program2-3.jsp?top_serl=99329866\& key_word=\&owner_dep $=\&$ meet_date_dd $=2 \&$ meet_date_mm $=10 \&$ meet_date yyyy $=2561 \& d o c \_i d 1=\& d o c \_i d 2=\&$ meet_date_dd $2=\&$ meet_date_mm $2=\&$ meet _date_yyyy2=.

185 Prachatai. 2016. 'We Move Exposes the Plethora of Flaws in the Meechai Constitutional Draft' 1 February. Retrieved 29 November 2019, https://prachatai.com/journal/2016/ $02 / 63826$.

186 The Secretariat of the Cabinet. 2018. 'Cabinet resolution on the Examination Report on Proposals to Solve the Problem [Concerning Civil Rights related to the Freedom of Expression in the Case where National Security Officials Ordered We Move to Stop their Symposium on the Draft Constitution', 10 April. Retrieved 29 November 2019, http:// www.cabinet.soc.go.th/soc/Program2-3.jsp?top_serl=99328202\&key_word=\&owner _dep $=\&$ meet_date_dd $=10 \&$ meet_date_mm $=04 \&$ meet_date_yyyy $=2561 \&$ doc_id $1=\& d$ doc _id $2=\&$ meet_date_dd $2=\&$ meet_date_mm2 $=\&$ meet_date_yyyy $2=$.

187 Ibid. 
announcement prohibits political gathering, reasoning that such gathering undermines national security. ${ }^{188}$

In the 'We Move' case, the NHRCT called on the government to enact laws that provide reparations to victims of state-sponsored human rights violations. The government responded that it had already determined, in consultation with the Ministry of Justice, that the legislation proposed by the NHRCT would not be necessary, citing the absence of such laws in Germany and other countries. ${ }^{189}$ This example shows that the government does not heed the NHRCT's voice when it acts on behalf of citizens who criticize the government, making it impossible for the N HRCT to bring about any meaningful solution to redress these human rights violations.

In the highest degree of unresponsiveness, the government does not even acknowledge the NHRCT's statement with respect to a human rights complaint, acting as if the action which gave rise to the complaint never happened. This is seen in cases where the political image of the government is severely tarnished, such as the Rajabhakti Park incident. ${ }^{190}$ Here, governmental officials were accused of corruption in building the Rajabhakti (meaning loyalty to the monarch) Park. A group of protesters, most of them university students, arranged a train ride from Bangkok to the Park located in Hua Hin. Their train was stopped by government officials and all protesters were subsequently arrested.

Upon their pre-trial release, they brought a complaint to the NHRCT. The NHRCT issued a statement to the relevant authorities, but did not receive any form of co-operation: no response was given, no official came to testify or provide information. ${ }^{191}$ After only a few days, the NHRCT had to announce the

188 Ibid.

189 The Secretariat of the Cabinet. 2018. 'Cabinet resolution on Recommendations and Proposals on the Amendment of Laws to Solve Problems in Compensating for $\mathrm{Hu}-$ man Rights Violations and Compensation in line with Humanitarian Principles', 30 January. Retrieved 29 November 2019, http://www.cabinet.soc.go.th/soc/Program2-3 .jsp?top_serl=99327505\&key_word=\&owner_dep=\&meet_date_dd $=30 \&$ meet_date _mm $=01 \&$ meet_date_yyyy $=2561 \& d o c \_i d 1=\& d o c \_i d 2=\&$ meet_date_dd $2=\&$ meet_date _mm2 $=\&$ meet_date_yyyy2=.

190 Thairath. 2015. "Train ordered to stop at Baan Pong Station, "Jaa New's" Train Coach Detached to Stop him Reaching "Rajabhakti"' 7 December. Retrieved 29 November 2019, https://www.thairath.co.th/content/545606.

191 National Human Rights Commission of Thailand. 2015. 'Statement of the National Human Rights Commission (NHRC) regarding the case of Rajabhakti Park' 8 December. Retrieved 29 November 2019, http://www.nhrc.or.th/NHRCT-Work/Statements-Press -Releases-Open-Letters/Statements. 
closure of the examination of this complaint. ${ }^{192}$ The tarnish to the government's political image here was very severe-it was accused of corruption in building an homage to the monarchy, the very institute it swore to protect. In such case of severely damaged political image, it can be seen that the government's unresponsiveness is complete.

On the issue of unresponsiveness and non-compliance from governmental agencies, Paweena Chaneid, Legal Officer of the N HRCT remarks that, in reality, when the NHRCT makes a recommendation, the non-compliant agencies do not need to follow it. There is no legal binding force which can compel such agencies to stop the violating act or compensate victims. The non-compliance is without sanction. ${ }^{193}$ This means governmental agencies are free to comply with the recommendations or not. Thus, compliance depends rather on the attitude of the individual agency. She further comments that the deficiency in the law which does not equip NHRCT's recommendations with a sanction or legally binding effect is a major impediment in the NHRCT's work, especially in cases where the agency accused of committing a human rights violation is an agency related to security, such as the Police Department and the Ministry of Defence. ${ }^{194}$ These agencies usually ignore the reports that the NHRCT submits, because they think it is merely a paper and has no power of enforcement. ${ }^{195}$

On this same point, Wat Tingsamitr, the current NHRCT Chairperson, made an interesting remark. The NHRCT is one of the governmental organizations supported by governmental budget. It has a mandate to receive complaints from the people, but in reality, if such complaints expose corruption or undermine the government's policy and actions, their political relevance makes it difficult for the NHRCT to deal with them. ${ }^{196}$

Also the Former Commissioners of the NнRCT Tuenjai Deetes, and Angkhana Neelaphaijit, both of whom resigned on 31 July 2019, profess a similar opinion. According to the amended Organic Act of 2017 on the NHRCT pursuant to the new Constitution, the cabinet must reply to the NHRCT upon receipt of the NHRCT's report on examination of human rights violations which

192 Thairath. 2018. 'NHRCT Closes Human Rights Violation Examination of University Students being Stopped on the Train to "Rajabhakti" 2 February. Retrieved 29 November 2019, https://www.thairath.co.th/news/crime/1193730.

193 Paweena Chaneid, Legal Officer of the NHRCT. (11 November 2019). Personal interview.

194 Ibid.

195 Ibid.

196 Wat Tingsamitr, Chairperson of the NнRCT. (21.00: 9 January 2019). Interviewed by the Thai Parliament Radio Channel FM 87.5 MHz, http://live.parliament.go.th/livevideo/ b6o882efebe8ef971egd482gaa6eo12e. 
contains its policy and legal recommendations. ${ }^{197}$ In practice, the NHRCT has mostly received a reply stating that the cabinet has noted the NHRCT's report. ${ }^{198}$ No detail has been given as to the possibility, manner, and extent of implementation of the recommendations by the agency.199 Angkhana remarked on the difficulty in carrying out her task as Commissioner. She mentioned that the work environment and administration in the present Commission has not been conducive, which made her unable to exercise her potential to the fullest. As a result, she decided to end her duties.

\subsection{A Comparative Analysis}

The greatest impacts to the effectiveness of both NHRIs in carrying out their mandates to protect human rights are set by their respective national governments. These impacts are both political and legal. However, one may argue that whereas in the Philippines the government mainly employs political channels to obstacle the NHRI's work, the Thai government mainly employs legal channels.

The first political means that the Philippine government uses to impact the CHRP's effectiveness comes in the form of President Duterte's rhetoric against human rights. Such rhetoric imposes on the public the opinion that human rights defenders are enemies of the state, that human rights stifle progress and undermine security, and that causes of human rights are insignificant and to be ignored. The effect of this rhetoric against human rights is that it closes the political space in which the CHRP works by limiting the acceptance of the CHRP and making it difficult to mobilize support from the majority of the population to subscribe to the concept of human rights.

The second political means is Duterte's public acquiescence of the war on drugs. The CHRP's work on facilitating the administration of justice in the case of extrajudicial killings has been hindered by the authorities carrying out Duterte's policy, who have tampered with evidence and refused to cooperate with the CHRP's investigations. Additionally, the environment of impunity and violence created by Duterte's rhetoric against human rights can be said to prevent victims from coming forth to testify in CHRP investigations.

In addition to the political means, the Philippine government also employs legal means to impact the CHRP's effectiveness. Such legal means can be seen in two instances. The first instance is the National Expenditure Program

197 Khaosod. 2018. "NHRCT" Criticizes the Government for Receiving Human Rights Violations Report and Merely Replying “Noted” without Caring to Solve the Problem' 22 April. Retrieved 29 November 2019, https://www.khaosod.co.th/politics/news_994223.

198 Ibid.

199 Ibid. 
cutting the budget of the CHRP, passed by Parliament upon the government's proposal. Without sufficient funds, the CHRP cannot carry out its extensive mandates, particularly for what concerns the provision of financial assistance to complainants. The second instance is the use by the Philippine government of the legal mechanisms available in the Rome Statute of the International Criminal Court to withdraw membership from the Statute. Since gross violations of human rights can constitute international crimes, the ICC has a significant bearing on human rights. The Philippine government's withdrawal from the Rome Statute thereby disconnects the CHRP's international network. It should also be recalled here that Duterte mentioned a possible abolition of the CHRP by way of constitutional amendment.

As for Thailand, the government's ways to impact the effectiveness of the NHRI are very different from the ones employed by the Philippine's government. For what concerns the government's rhetoric against human rights, like in the Philippines, the Thai head of government has communicated a negative message when speaking about human rights causes and the national human rights institution, however, the remarks made by the Thai government are definitively less blatant and less extreme. Therefore, it can be said that the impacts to the NHRCT's effectiveness set by the Thai government through antihuman rights rhetoric are minor.

The Thai government-sponsored actions against the NHRCT are pursued under the cloak of law. Two examples can be made. Firstly, the junta has used the immense power granted to it by Section 44 of the Constitution to justify acts which violate human rights, particularly towards political opponents. ${ }^{200}$ Such constitutionality shields the government from being declared accountable by the N нRCT. Secondly, the military government has introduced a reform of the NHRCT in 2016 whereby the NHRCT's mandate to bring a claim to court has been revoked, clearly impacting its capacity to redress human rights violations. It is notable to mention here for purposes of comparison that, unlike in the Philippines where proposals of budget cuts have been made (and accepted by Parliament), in Thailand, the government has not yet proposed any budget cut with respect to the NHRCT.

Finally, the government uses a loophole in the law to be unresponsive to the NHRCT's requests and recommendations, particularly in cases which

200 Section 44 refers to a constitutional provision that grants the Head of the NCPO, a position occupied by Prayuth Chan-Ocha, the Prime Minister, the wide-ranging power to order or perform any legislative, executive, or judicial act that he deems necessary to reform the country, to enhance the unity of the citizens, and to prevent any act which undermines, inter alia, public order or national security. Section 44 also guarantees that the orders and the acts will be deemed lawful and constitutional and that they are be final. 
directly affect its political image. This unresponsiveness means that the NHRCT does not receive cooperation in addressing human rights violations, rendering their examination and recommendations obsolete. As a result, the NHRCT cannot solve cases of alleged human rights violations against governmental agencies.

Conclusions and Recommendations

Both the CHRP and NHRCT occupy a position of high importance as the national human rights institution of their respective countries, carrying out their legally mandated role of helping to protect the human rights of the citizens. At the same time, both the CHRP and NHRCT have faced significant challenges in performing their mandates under their respective national government's policies which are not pro-human rights in the last few years. In the Philippines, President Duterte implements the policy on the war on drugs since 2016, raising human rights issues of extrajudicial killing. In Thailand, the taking over of the military government since 2014 has given rise to human rights violations especially towards anti-government groups and individuals.

To answer the first research question on the extent to which the CHRP and NHRCT have been mandated to protect human rights, it could be said that the two NHRIs share the same core mandates to receive complaints of human rights violations, to investigate them, and to try to solve the complaints through mediation, recommendation of remedial measures to the concerned parties, and through referral to legal channels. However, the particularities in carrying out these mandates are different.

Firstly, with respect to the difference in their powers to investigate or conduct examinations, the CHRP's powers are more extensive than those of the NHRCT. The CHRP's powers to investigate alleged human rights violation extend beyond the obvious task of finding facts from relevant parties. The CHRP can offer witness protection while investigations are being conducted and provide legal and even medico-forensic assistance to victims while the NHRCT cannot. This means the CHRP's mandates are truly based upon all needs of a victim of human rights violations in the course of investigation. In contrast, the NHRCT has only examination powers which allows it to request the appearance of persons and the submission of evidence. This ability is already inherent in the course of the act of fact-finding, so it can be said that the provisions on these inherent powers are merely a clarification, or exemplification of what the NHRCT may do. 
Secondly, with respect to the difference in their powers to facilitate the access of victims to the judicial process, the CHRP is endowed with the power to make a complaint directly to a prosecutor, bypassing the police. On the contrary, the NHRCT is merely able to send a case to the inquiry official, and this official will then have to investigate the case, and later send the files to a prosecutor. Then the prosecutor will review the files, and make a decision on whether to prosecute or not. This shows that a complaint made to the NHRCT has to undergo a greater number of processes if compared with the CHRP.

Thirdly, in connection with the difference in their powers to resolve complaints, the CHRP is able to better address the suffering of the complainants. The CHRP can actually provide financial aid to victims of human rights violations. The financial aid is determined by the gravity of the violation, the economic status of the complainant, as well as the expenses incurred from the violation. In contrast, the NHRCT may only reimburse the transportation expenses a person has incurred from travelling to the NHRCT to give testimony concerning an alleged human rights violation but is not empowered to provide any financial aid to contribute towards the redress of a human rights violation itself. As such, it can be said that the Philippine NHRI has a stronger and more comprehensive protective capacity than the NHRI of Thailand.

For what concerns the answer to the second research question- how the governments of the Philippines and Thailand have impacted the effectiveness of the CHRP and NHRCT in carrying out human rights protection work according to their legally established mandates-, this paper observes, on the basis of evidences contained in the previous sections, that the ways in which the Philippines and Thai national government impact the performance of both NHRIs are very different. In the Philippines, such impacts are both political and legal, whereby the merely political actions take the lion's share. On the contrary, in Thailand, the governmental actions impacting the NHRI's effectiveness primarily take the form of legal impacts.

In the Philippines, an important political impact to the NHRI's effectiveness is President Duterte's rhetoric against human rights, which ultimately closes the political space in which the CHRP works by limiting the acceptance of, and consequently the support for the CHRP. In the extrajudicial killing cases, the CHRP faces great difficulties in facilitating the administration of justice and has also been actually hindered as the authorities carrying out Duterte's policy have tampered with evidence and refused to cooperate.

As for the legal means, the government under presidential control proposed, and successfully obtained by Parliament, significant cuts in the CHRP's budget. It has also considered abolition of the CHRP and further hindered the CHRP's 
interaction with the international human rights system. The government managed to withdrew the Philippines from the Rome Statute of the International Criminal Court, effectively disconnecting networks of cooperation between domestic and international organizations that are able to support the CHRP's work.

In Thailand, the government mostly employs legal ways to impact the NHRCT's work. The government-controlled process of the drafting of the Constitution of 2017 was aimed to make this Constitution comply with their political wills. Protective mandates which the NHRCT used to hold in the past were withdrawn. Enabled by legal loopholes, governmental unresponsiveness has further hindered the efforts of the NHRCT. Particularly cases which directly affect the State's political image or exposes its corruption have been ignored by the government, despite the NHRCT having sent them recommendations to redress such human rights violations. This unresponsiveness means that the NHRCT does not receive cooperation in addressing human rights violations, rendering their examination and recommendations obsolete.

To conclude, this paper argues that even though the law and the Constitution in the Philippines and Thailand provide several protective mandates to the NHRIs, too many legal gaps are still open for the governments to interfere with the NHRIs' work both politically and legally. From this paper it is evident that these two governments employ both political and legal tools to hinder NHRIs' capabilities to protect their own interests, whether that be to pursue extrajudicial killings of suspected drug dealers in the case of the Philippines or to silence political opponents in the case of Thailand.

This paper therefore recommends that in order to enable both NHRIs to deal more effectively with human rights violations, they should have, first, a stronger and more wide-ranging legal mandate. It would be opportune to consider establishing additional mandates even beyond those which are required by the Paris Principles. Important additional mandates include those that allow the NHRIs to support victims to access a fair trial and receive suitable compensation. An interesting and potent competency to grant to NHRIs is the ability to impose sanctions upon governmental agencies that the NHRI finds have violated human rights. It is recommended that the sanctions are recognized throughout the entire system of government.

To fortify NHRIs' strong legal mandates and to ensure NHRIs are able to effectuate them in reality, political support is also required. Given the fact the national governments are an important obstacle to the NHRIs' performances, a strong regional human rights protection institution is needed to fill the effectiveness gap of NHRIs. Such a regional human rights protection institution should be capable to address human rights violation complaints made by 
individuals, and to compel states to comply with their obligations to safeguard human rights. Together, this legal and political support of NHR Is would ensure that the powerful interests of governments do not prevail over the interest to protect human rights, especially of the most vulnerable members of society in the region. 